\title{
China's Banking Reform: An Assessment of its Evolution and Possible Impact
}

\author{
Alicia García-Herrero*, Sergio Gavilá ${ }^{\dagger}$ and Daniel Santabárbara*
}

\begin{abstract}
The Chinese banking system, characterized by massive government intervention, poor asset quality and low capitalization, has started a reform process based on the three main pillars: (i) bank restructuring, through the cleaning-up of non-performing loans (NPLs) and public capital injections, particularly in the four largest state-owned banks; (ii) financial liberalization, with the gradual flexibilization of quantity and price controls, the opening-up to foreign competition and cautious steps towards capital account liberalization and (iii) strengthened financial regulation and supervision, coupled with efforts to improve corporate governance and transparency. Although the reform is still ongoing, our preliminary assessment indicates that there has been an improvement in the soundness of the Chinese banking system. However, changes in the reform strategy are needed for it to be fully successful. Asset quality has improved, particularly in the recapitalized banks, but there is a high risk of a new build-up of NPLs. Capitalization has increased in the largest banks, as a consequence of the government capital injections, which generally remains low, as well as profitability. China's huge financing needs, to maintain high economic growth, and its commitment to fully open up its banking system to foreign competition urgently require a more comprehensive and time-bound strategy, with a longterm vision of the desired structure of the Chinese banking system. Bank recapitalization should be completed immediately, not only to ensure bank soundness, but also to increase profitability, which could be further hampered as the competition increases with full financial liberalization. Bank recapitalization, however, needs to be accompanied by a radical improvement in corporate governance, which would clearly be facilitated by a change in the property structure. (JEL classification: E44, E66, G2, G21)
\end{abstract}

Keywords: Chinese financial system, financial reform, bank restructuring, financial liberalization, bank regulation and supervision

\section{Introduction}

China's very high and stable growth in the last few years would seem to indicate that the country is a success in all regards, including finance. This optimistic picture, however, may change if we consider the extremely

* Bank of Spain, e-mail: alicia.garcia-herrero@bde.es

All authors are affiliated with the Bank of Spain. The opinions expressed are those of the authors and not necessarily those of the Bank of Spain. The article has benefited from inputs from the staff of the Chinese Banking Regulatory Commission and the Asian Development Bank as well as information from Sayuri Shirai. We also thank the participants of the CESifo Conference on understanding the Chinese economy, in particular Christa Hainz and Tamara Trinh, and participants of an IMF Seminar where the article was presented. Finally, we thank an anonymous referee for useful comments. e-mail: sergio.gavila@bde.es

e-mail: daniel.santabarbara@bde.es

(C) The Author 2006. Published by Oxford University Press

on behalf of Ifo Institute for Economic Research, Munich. All rights reserved.

For permissions, please email: journals.permissions@oxfordjournals.org 
high domestic saving and investment ratios. In fact, for an average 40 percent domestic investment to GDP (fully financed by domestic savings), an 8-10 percent growth is not such a high return to investment. This is a very rough indicator of potential misallocation of resources, namely domestic savings, which has been a common feature of the finallyclosed economies, and even more so of the centrally-planned ones.

The Chinese authorities are in the process of transforming a planned economy into a market-based one. There are several reasons to believe that this process may have consequences not only for China but also for the rest of the world. First, China has one-fourth of the world's population and 15 percent of its GDP measured in terms of purchasing power parity (PPP). Second, its economy is expected to become even larger; for some, even the biggest, worldwide by 2050 (Wilson and Purushothaman 2003). Third, it is one of the main exporters of capital, which is now mainly directed to financing the US current account deficit.

In this study, we concentrate on the banking sector for three reasons. First, it is the most important player of the Chinese financial system, although capital markets are also growing fast. In 2004, bank loans represented 83 percent of the funds raised by the non-financial sector, while stocks were only 5 percent and bonds 12 percent (11 percent for government bonds and 1 percent corporate ones). Second, the banking system is the main financier of non-profitable state-owned enterprises (SOEs) so that bank reform will have a direct impact on SOEs. Third, the Chinese banking system is so large that the way in which the reform is resolved could have systemic consequences. One can think of several - albeit unlikely - scenarios for such consequences. One is a banking crisis, particularly in the aftermath of capital account liberalization, which could affect capital flows elsewhere in the world. Another one would be that a number of foreign banks gain control of China's largest banks, which rank among the largest in the world. This might induce a reshaping of the international banks' position worldwide and, perhaps, even a change in their interest towards other emerging economies.

This article describes and assesses China's ongoing banking reform as well as the potential impact of remaining measures, so as to draw conclusions and recommendations, which may be of interest for policy makers.

The article is organized as follows: In Section 2, the structure and evolution of the Chinese banking system is briefly described as well as the main reasons for its poor performance. Section 3 summarizes the main steps taken towards financial reform, distinguishing between bank restructuring, financial liberalization and bank regulation and supervision. Section 4 evaluates the impact of the reform on bank performance so far as well as the potential consequences of remaining steps. Finally, in Section 5, we draw conclusions and policy recommendations based on our evaluation of the reform. 


\section{The Chinese banking system}

In this section, we review the main features characterizing China's banking system so as to better understand and assess the steps taken for its reform.

The first striking feature is the large size of the banking system not only in relative terms but also in absolute ones. China ranked seventh, worldwide, in terms of bank credit to the private sector as a percentage of GDP (Figure A1 in Appendix 1) and sixth in terms of bank credit in United States Dollar (USD) (Figure A2 in Appendix 1). Furthermore, bank credit continues to grow at a brisk rate, pushed by buoyant economic growth. However, this does not imply a very developed banking system since penetration of banking products is low and bank credit for small-and medium-size enterprises (SMEs) and households is scarce, 15 and 11 percent of the total loans, respectively, in 2004.

The Second feature, as many transition economies, the Chinese banking system has been dominated by four very large State-Owned Commercial Banks (SOCBs), which were created in the 1980s to grant credit to key sectors and are now commercial banks concentrating in corporate lending (Appendix 2 offers an overview of the institutional setting of the Chinese banking system and the different types of banks). The remaining banks are relatively small, which explains why the degree of concentration is relatively high when measured in terms of the share of assets of the four largest banks (see $\mathrm{m}_{4}$ in Figure 1), but much lower when measured by the Herfindahl Index. The relatively low Herfindahl Index, however, does not imply strong competition in the banking system, given the oligopolistic behaviour of the SOCBs, the still massive government intervention and the ample room for growth that the strong demand for credit has offered to all banks. A proof of the scarce competition is the relatively high interest margin, at least when compared with industrial countries (1.79 percent in 2003 as opposed to 1.38 percent for EU banks). ${ }^{1}$ Things seem to be starting to change with the decreasing weight of SOCBs in the banking system (with 73.9 percent of the total assets in 1993 and 54.6 percent in 2004) and the rising importance of other commercial banks, such as the Joint-Stock Commercial Banks (JSCBs) and the City Commercial Banks (CCBs). The former, partially owned by local governments and SOEs, and with a growing share of private ownership (sometimes foreign), now hold 15 percent of the total bank assets, as compared with 4.4 percent in 1993 . The CCBs, created by restructuring and merging urban credit cooperatives (UCCs), are much smaller, with a 5.4 percent share in 2004

1 The net interest margin is even higher in Eastern Europe (3.39 percent), which may point to the lack of competition notwithstanding the systemic restructuring their banking systems went through in the 1990s. 


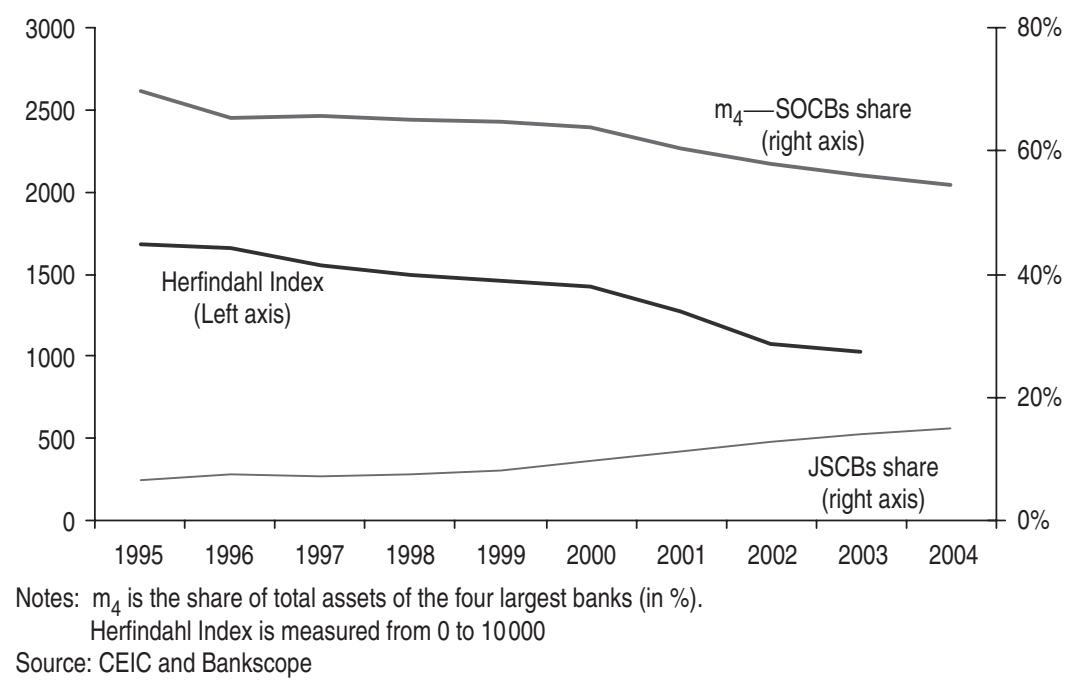

Figure 1 Concentration of the chinese banking sector

(Table A1 in Appendix 1 shows the evolution of asset share for each type of institution). This rapid change in asset share is mainly driven by a 30 percent yearly growth in JSCBs' assets, as opposed to 10 percent for SOCBs.

The third feature is the rather peculiar structure of the balance sheet, compared with international standards. First, loans are a large part of the assets (60.8 percent in 2003 as shown in Figure 2), the majority of which is granted to the corporate sector (over 85 percent of the total loans and over 85 percent of the profits) and to a large - although decreasing - extent short-term. In fact, still nearly 50 percent of the total loans go to finance industrial projects in a revolving manner (Table A4 in Appendix 1). This is particularly the case of policy banks, created in 1994 as state-owned development banks, with 92 percent of assets in loans. The recent boom in the housing sector has not changed this picture yet; mortgage lending is still $<15$ percent of the total loans, but also of new loans (as shown in Figure 3). Second, almost all liabilities are deposits, with an average share of 89 percent in 2003. This is even higher in SOCBs (92 percent) but much less so for JSCBs (79 percent), which have used non-interestbearing funding. Retail depositors are the main financiers of the banking system since corporate deposits only represented one-third of the total. (Tables A2, A3 and A4 in Appendix 1). Again, large differences exist among types of banks since retail depositors represent 60 percent of the total deposits for SOCBs and corporate deposits 65 percent for JSCBs. 
A. García-Herrero et al.
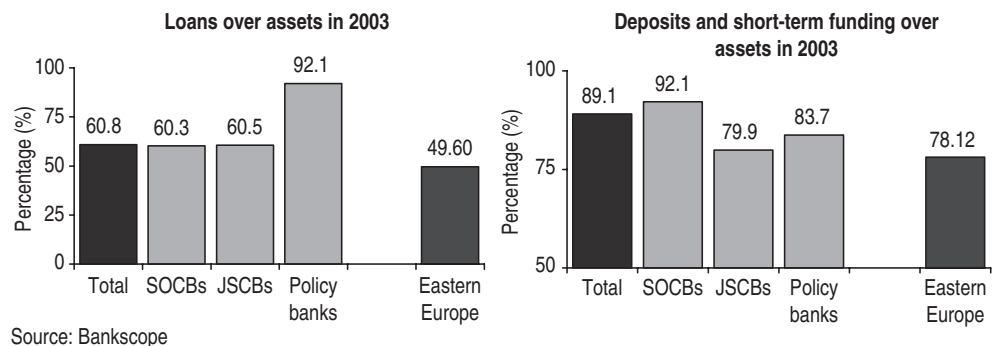

Figure 2 Assets and short term liabilities

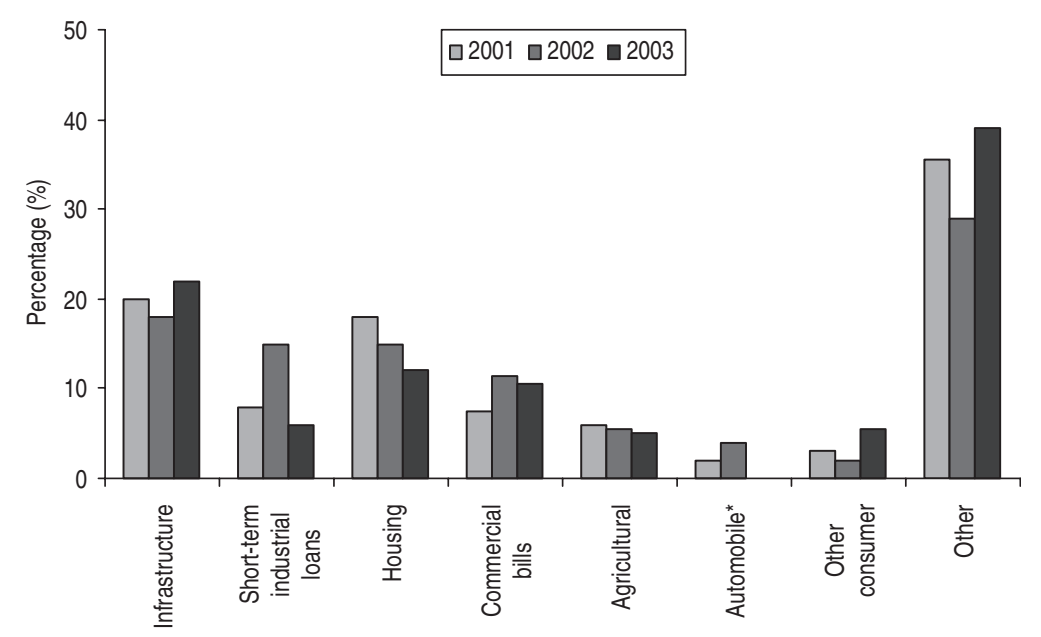

Source: Standard and Poors (2004)

Figure 3 Composition of new loans

The fourth feature of Chinese banks, also rather common in transition economies, has been their very poor asset quality. The ratio of nonperforming loans (NPLs) to total loans was 20 percent in 2003 (Table 1), well above the other emerging economies standards (9.1 percent for Eastern Europe banks in the same year). The situation was even worse before the Chinese authorities started their restructuring [above 30 percent in 1997 according to the China Banking Regulatory Commission (CBRC)]. Also provisioning, as a percentage of NPLs, was well below the international standards, namely $<22$ percent, ${ }^{2}$ as compared with

2 Due to data limitations, this ratio has been calculated for three of the four SOCBs (i.e. excluding the Agricultural Bank of China), and ten of the twelve JSCBs. 
Table 1 Reported NPLs in Chinese financial system

\begin{tabular}{llllr}
\hline & & & $\begin{array}{l}\text { NPL ratio } \\
\text { (\% of total } \\
\text { loans })\end{array}$ & $\begin{array}{l}\text { US of } \\
\text { GDP }\end{array}$ \\
\hline State-owned commercial banks & Dec-03 & 232 & 20 & 17 \\
Joint-Stock Commercial Banks & Mar-04 & 23 & 7 & 2 \\
Policy Banks & Jun-03 & 19 & 18 & 1 \\
Credit cooperatives & Mar-04 & 60 & 30 & 4 \\
Banking system total & Dec-03 & 373 & 19 & 28 \\
Asset management companies & Dec-03 & 107 & - & 8 \\
Financial system total & Mar-04 & 480 & - & 36 \\
& & & &
\end{tabular}

Source: Authors' own estimations based on official figures reported by Bofit (2004), Ernst and Young (2004), Ping (2003) and Pei and Shirai (2004).

aJune 2003 annual GDP.

46.4 percent in Eastern Europe in 2003. The underlying reasons for such poor asset quality are not only the soft-budget constraints for lending to SOEs but also a weak credit culture. The former is a well-known problem of transition countries, all the more so, the longer does the transition lasts towards a market economy. ${ }^{3}$ The latter explains why NPLs from SMEs and household lending are also high for international standards. Finally, capitalization is low. The solvency ratio, calculated according to Basel I, was only 6.73 percent $^{4}$ in 2003 (as shown in Figure 4) and the ratio of equity to assets was 4.3 percent, virtually the same as before the reform started, and very low compared with Eastern Europe in 2003 (10.3 percent). Table A5 in Appendix 1 shows the evolution of basic indicators of bank performance for each bank group.

The fifth feature is a very poor profitability. In 2003, the return on equity (ROE) of the banking system was 3.05 percent (Figure 5), and the return on average assets (ROA) was 0.14 percent, well below the international standards. As an example, Eastern Europe banks had 13.57 percent ROE and 1.43 percent ROA in the same year.

There are several reasons for the low profitability, but the main one seems to be asset quality. Operating income, as a percentage of

3 A wealth of literature exists on the relation between political interference and the performance of the banking system. For example, see Brandt and Li (2003), Chang (2003), Cull and Xu (2000), Moreno (2002), Park and Sehrt (2001), Wei and Wang (1997) and Zhou (2004).

4 The solvency ratio has also been calculated for three of the four SOCBs and ten of the twelve JSCBs. 

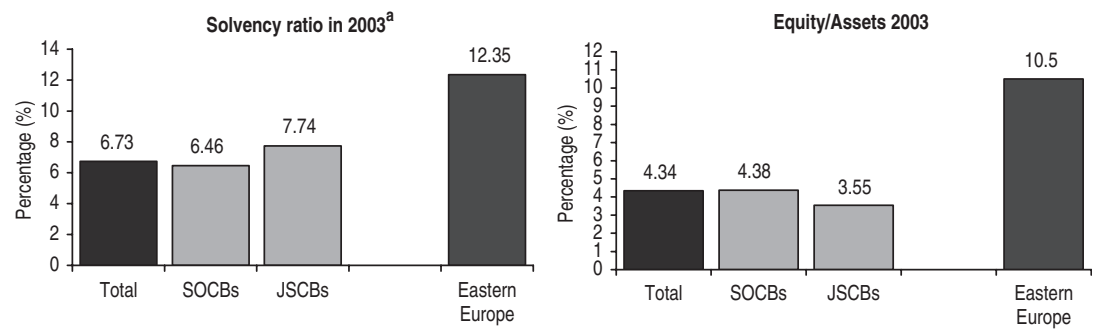

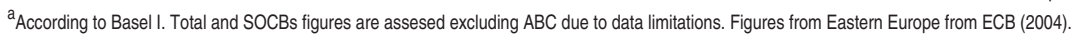
Source: Bankscope

Figure 4 Capitalization indicators
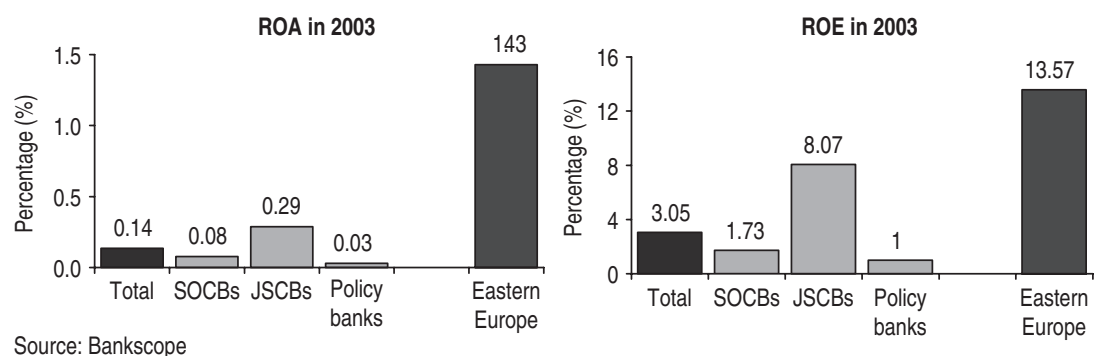

Figure 5 Profitability indicators

total assets, is lower for Chinese banks than for Eastern European ones (2.22 percent compared with 5.93 percent in 2003, as shown in Figure 6), but much more so for non-interest income (Figure 7). The efficiency of Chinese banks, measured by the cost to income, is actually better, (51.68 percent compared with 62.27 percent in the same year), although it is basically explained by lower wages. In fact, other measures of efficiency, such as pre-provision profit over employees generally ranks EU banks better than Chinese. Besides the lower operating income, the difference in profitability is mainly explained by the much larger amounts of provisions and write-offs, stemming from the very low asset quality. In fact, provisions and write-offs, apart from taxes, reduce Chinese banks' net income to only 11.7 percent of the pre-provision profits in 2003, compared with 56.6 percent for Eastern European banks. Tables A2, A3 and A6 in Appendix 1 depict the evolution of assets, liabilities and income and expenditure for different types of Chinese banks.

The Sixth feature is that the state-ownership is pervasive and corporate governance is very weak. The root of this problem is government intervention, which inhibits banks allocating their assets according to 

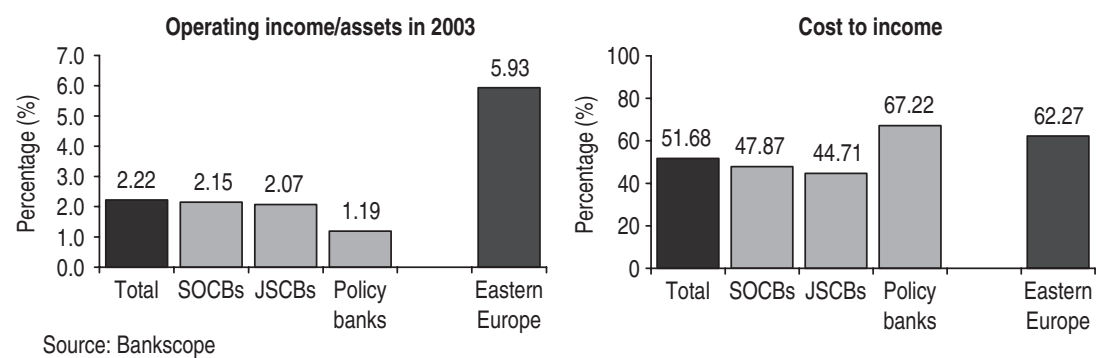

Figure 6 Efficiency indicators
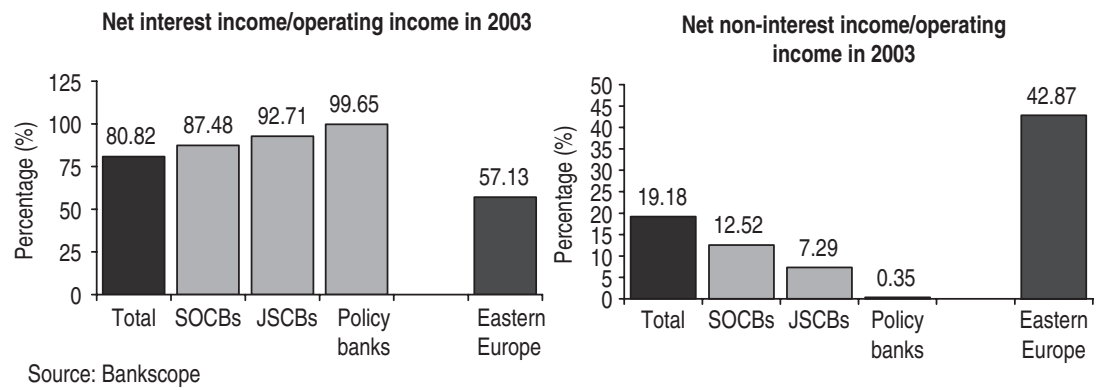

Figure 7 Source of income

market criteria. ${ }^{5}$ This is particularly true for the SOCBs. The SOCBs lack the basic attributes of a profit-making bank. In fact, they do not have clearly identifiable owners, or, until very recently, the board of directors or specialized organs for monitoring management. They only have an external board of supervisors - as all Chinese companies - which monitors conformity with banking law and regulations, but has no role in the governance or oversight of bank management. Banks are accountable only to the government (usually the Ministry of Finance) and disclosure requirements are minimal. Finally, the management has traditionally been selected from the ministerial system and has remained subject to the close control of the party. The JSCBs do not have the same legacy as SOCBs so that their management has a higher commitment to shareholder value although they are still very much influenced by local governments and government-controlled enterprises given their large participation in the capital of most of these institutions. The JSCBs have also introduced

5 The problem of government intervention has been well-documented in La Porta, LópezDe-Silanes and Shleifer (2002) and Sapienza (2004). 
improvements in the procedures for granting credit and risk management. Some of the largest CCBs are in a similar position to JSCBs, but not the small ones which still resemble the UCCs. Credit cooperatives are characterized by an even weaker governance than SOCBs, since they are subject to direct control from local governments.

The last feature is the poor institutional framework of the banking system. This is featured by a rather loose regulation and supervision, particularly as regards enforcement. Furthermore, the regulatory bodies, as well as the central bank, are dependent on the party's decisions. The lack of enforcement power from the supervisory part helps explain the very limited improvement in corporate governance. Additional weaknesses are the lack of a bankruptcy law, a national credit bureau and a smooth functioning of the payment systems.

\section{Steps taken in banking reform}

The reform of the Chinese banking system started with an institutional shake-up, as was generally the case in transition economies. The first and the foremost important step was the substitution in 1984, of a monobank system with a multi-tiered one, in which central banking functions were separated from the rest. The second step was the separation of commercial banking activities from those specially geared towards economic development. To this end, policy lending banks were established in 1994 in order to take over from SOCBs projects for development purposes and a new Commercial Banking Law was approved in 1995 to regulate commercial banks. Third, the institutional design of the People's Bank of China (PBC) was strengthened through a new charter in 1995, where its three main responsibilities were: monetary stability, banking supervision and oversight of the payments system. The new charter, however, did not grant the PBC independence from the State Council. Finally, responsibilities for monetary policy and banking supervision were separated with the creation of the CBRC in 2003.

In addition to the institutional shake-up, China's bank reform has been based upon three main pillars: (i) bank restructuring, through the cleaning up of NPLs and recapitalization; (ii) the reduction of government interference in the system, through quantity and price liberalization as well as opening up to the foreign competition and (iii) improved regulation and supervision.

\subsection{Restructuring}

Bank restructuring has probably been the most important pillar of bank reform since poor asset quality, coupled with very low capitalization, 
was a very pressing problem. Bank restructuring has, until now, mainly focused on SOCBs but there have also been some measures for credit cooperatives. This section concentrates on SOCBs, given their systemic natures. The SOCBs' restructuring process has not been linear but in waves. Three can be clearly identified, each of which with two clearly differentiated steps: first a capital injection and, second, the clean-up of NPLs.

\section{The three restructuring waves for $S O C B s$}

The first wave started in 1998, with an injection of the equivalent of USD 33 billion in Renminbi (RMB) into the four SOCBs. The operation started with a reduction in the reserve requirement which freed liquidity for the banks to acquire government paper. The government transferred again the receipts of this purchase to these banks in the form of fresh capital. This operation was followed, in 1999-2000, by the transfer-at book value - of NPLs from the four $\mathrm{SOCBs}^{6}$ to the four newly created Asset Management Companies (AMCs) for the equivalent of USD 170 billion (more details on the functioning of these AMCs are given in the next section).

The second wave started in December 2003 with USD 22.5 billion capital injections in the two best-performing SOCBs, namely the China Construction Bank (CCB) and the Bank of China (BoC). ${ }^{7}$ These injections came directly from the country's official international reserves, through the transfer of rights of ownership of US government bonds. These have not been converted into RMB yet because of imposed restrictions. Since each bank's existing capital was mainly used to provision or write-off, the equivalent of USD 23.4 billion in NPLs, this operation led to a very marginal increase in capitalization while asset quality did improve substantially. In June 2004, the equivalent of USD 15.6 billion and 18.1 billion in NPLs was auctioned from CCB and BoC, respectively, to AMCs at 50 percent of the face value. The provisions accumulated with the capital injections were used to write-off the other 50 percent of the value. Cinda, the most active $\mathrm{AMC}$ won the auction by promising a 30 percent recovery rate. In addition, $\mathrm{CCB}$ and $\mathrm{BoC}$ increased their Tier II capital by issuing subordinated debt for the equivalent of USD 4.8 billion and 7.3 billion, respectively. Finally, CCB listed part of its shares in Hong Kong in October 2005 and the listing of the BoC has been

6 NPLs were also transferred from one policy bank (China Development Bank).

7 Table A7 in Appendix 1 gives details of NPLs at each SOCB. 
announced for 2006 and a state-owned investment company has been created to organize the listing. Chinese authorities have expressed interest in strategic investors entering these banks' capital in order to diversify ownership and improve management quality. This has been shown by the Bank of America's recent acquisition of a 9 percent stake of CCB (amounting to USD 2.5 billion), before the actual listing. This has been followed by an additional USD 1 billion stake in CCB by Singapore's state-owned financial holding, Temasek.

The third restructuring wave started in April 2005 with the injection of USD 15 billion into the Industrial Commercial Bank (ICB). As for the second wave, these funds came from the official international reserves and have not been converted into RMB. Although the share of NPLs in this bank is much larger than in the previously restructured ones, only USD 9 billion of the previous capital was used to provision NPLs while the remaining USD 15 billion was retained in equity (i.e. total equity is now USD 30 billion). The restructuring continued in June 2005 with the approval of an NPL disposal of USD 85.5 billion to AMCs and the issuance of USD 12.1 billion in subordinated debt. In the same way as $\mathrm{CCB}$ and $\mathrm{BoC}$ did, ICB plans to be listed in 2006 or $2007 .^{8}$

In these three waves, an estimated 20-24 percent of the 2004 GDP has been injected in the banking system, ${ }^{9}$ either as capital or as a substitute of NPLs. This amounts to over 110 percent of the SOCBs' capital in injections.

\section{The NPLs' disposal}

As previously mentioned, the Chinese authorities established a number of AMCs where NPLs from SOCBs have been transferred and their staff seconded. AMCs are legally independent agencies with a very broad mandate, namely collecting NPLs, restructuring them or converting them into equity. They are also responsible for issuing bonds and borrowing from financial institutions to pay for the NPLs they receive. Finally, they are also in charge of restructuring SOEs and recommending companies for listing (Pei and Shirai 2004).

The original idea was to assign one AMC for each SOCB. The separation of NPL recoveries depending on the bank of origin was

8 The transfer of NPLs to an AMC and the issuance of subordinated debt are still pending.

9 If we assume that the purchase of NPLs in the third wave (i.e. from ICB) is carried out at face value as in the first restructuring wave, the estimated cost is 23.5 percent of 2004 GDP. If it is done at 50 percent value as in the second wave, the cost goes down to 20.7 percent of GDP. 
preferred by the Chinese authorities for several reasons. First, the average size of loans seemed to be small and the clients widely dispersed, making the recovery of NPLs more cumbersome. Second, the specialization of SOCBs, at least in their origin, meant that economies of scale could be rather limited. ${ }^{10}$ In reality, banks are no longer as specialized as they used to be and loans are sometimes very large, which might explain why this separate model has evolved into an auction, where AMCs bid to receive additional NPLs.

In the first restructuring wave, each AMC received NPLs from its respective SOCB at face value for a total amount equivalent to 8 percent of GDP (Table 2) and issued a 10 year bond with an annual 2.25 percent coupon for 83 percent of that amount and paid the remaining 17 percent in cash. In the second restructuring wave, auctions had been used to transfer NPLs. The action implied that the highest bidding AMCs, in terms of recovery value, namely Cinda, received the NPLs. In the third wave, a part of the NPLs were transferred to the Ministry of Finance, ${ }^{11}$ (USD 30 billion) and another was bought by the PBC at face value (USD 55 billion). The PBC, then, auctioned them at 26 percent of that value to the AMCs.

Excluding the third wave, which is still ongoing, the amount of NPLs which has been restructured or disposed of hovers around 50 percent of the total loans transferred. From the restructured (resolved) loans, only 20 percent of their nominal value has been cashed, which implies that only 10 percent of the nominal value of the NPLs transferred has been recovered. Only a marginal part of these NPLs has been securitized or purchased by foreign investors. Finally, the government has set the end of 2006 as deadline for the AMCs to work out all NPLs.

\section{Other restructuring efforts}

The other restructuring steps taken by the Chinese authorities concern the small financial institutions. Credit cooperatives, as well as Trust and Investment Corporations (TICs), underwent a consolidation from 2000 to 2002 through closures and mergers at the provincial level. In August 2003, given the undercapitalization of rural cooperatives and their incapability to rejuvenate the rural economy, additional measures were introduced with pilot projects and extended nationwide in June 2004.

\footnotetext{
10 For this reason, the main staff members of each AMC are generally seconded from the relevant $\mathrm{SOCB}$.

11 The Ministry of Finance seems to have taken the responsibility of covering the possible shortfall of revenues by the AMCs with the income taxes and dividends of ICB.
} 
Table 2 AMCs disposal of NPLs at March 2005

\begin{tabular}{|c|c|c|c|c|c|c|c|}
\hline $\mathrm{AMC}$ & SOCB & $\begin{array}{l}\text { Assets transferred } \\
\text { (USD billions) }\end{array}$ & $\begin{array}{l}\text { Share of banks } \\
\text { loans outstanding } \\
(\% \text { at end-1998) }\end{array}$ & $\begin{array}{l}\text { NPL } \\
\text { resolved }\end{array}$ & $\begin{array}{l}\text { NPL } \\
\text { resolved } \\
(\%)\end{array}$ & $\begin{array}{l}\text { Cash } \\
\text { recovery }\end{array}$ & $\begin{array}{l}\text { Cash } \\
\text { recovery } \\
(\%)\end{array}$ \\
\hline Orient asset management & $\mathrm{BoC}$ & 32.3 & 20.4 & 12.9 & 39.9 & 2.9 & 22.8 \\
\hline Cinda asset management & $\mathrm{CCB}$ & 45.0 & 21.7 & 18.56 & 41.2 & 6.2 & 33.6 \\
\hline Huarong asset management & $\mathrm{ICBC}$ & 49.2 & 17.9 & 25.9 & 52.6 & 5.1 & 19.9 \\
\hline Total & & 168.3 & 20.7 & 83.2 & 49.4 & 16.9 & 20.5 \\
\hline
\end{tabular}

Note: in USD billions at March 2005.

त. Source: PBC, CRBC, annual reports, BIS working paper No. 115. 
In particular, credit cooperatives were given specific milestone objectives which, if complied with, would allow them to receive new capital injections, as well as tax-breaks and subsidies, from the PBC or the local government. Otherwise loss-making institutions will need to be closed. The total number of rural credit cooperatives (RCCs) is targeted to be reduced from 30000 in 2004 to around 10000 by the end of 2007. Until now, the amount of government funds injected into credit cooperatives hovers around USD 40 billion.

Notwithstanding the restructuring, the government control on the credit allowances to farmers remains tight, given the importance attached to raising rural income. The second programmed step in the restructuring of credit cooperatives is clarifying their ownership structure and improving their management capacity. The longer-term objective is the consolidation of credit cooperatives to no more than 2000 (from over 32000 at the end of 2004) reaching the necessary capitalization level and providing enough credit to the rural sector.

In parallel to the credit cooperatives, the CBRC announced it would move ahead with the reforms of other types of financial institutions, including policy banks and AMCs. As for AMCs, foreign firms will be allowed to compete with, and ultimately buy stakes in China's AMCs.

\subsection{Financial liberalization}

Financial liberalization is another important pillar of bank reform in China. Having been a planned economy for so long, government intervention in the Chinese banking system was massive and still is, in certain aspects. Liberalization efforts have gone in several directions: first, introducing market practices in the functioning of the banking system; second, freeing interest rates; third, opening up to foreign competition and, finally, liberalizing exchange rate controls, which affect banks' transactions with the rest of the world.

\section{Introducing market practices}

Reducing the government intervention in the banking system started in the 1990s with a number of different actions. An important one was the reduction of reserve requirements from 20 to 8 percent in 1998 and again to 6 percent in $1999 .{ }^{12}$ In addition, the remuneration of excess reserves was lowered to discourage banks from hoarding liquid assets and encourage them to manage their assets. The last reduction took place in March 2005 (from 1.62 to 0.99 percent). This has implied a steady

12 More recently, there was an increase to 7 percent in September 2003 and to 7.5 percent in April 2004. 
reduction in liquid assets although they still remain at relatively high levels (Table A2 in Appendix 1).

In parallel, SOCBs were given more responsibility for their lending decisions and some of their credit quotas were removed. Another important step was taken in 1999, when government interference in commercial lending was forbidden, at least in formal terms, and private capital was allowed to enter JSCBs and CCBs.

\section{Interest rate liberalization}

Interest rate liberalization is an important element of China's efforts to enhance the role of market forces in resource allocation. It is also a prerequisite for increasing the competitiveness of financial institutions, introducing market-based monetary instruments and improving the monetary transmission mechanism.

The approach towards interest rate liberalization has been gradual and is not yet completed. As for the sequencing, interest rates in money markets and bond markets were liberalized first, followed by the gradual liberalization of the interest rates of loans and, only later, deposits. The very first measure was taken in 1996, when the interest rates in the interbank market were liberalized. In 1997, the interest rate in the bond repo market was also freed from controls and the issuing rate of government bonds started to be determined by market forces in 1998. Controls on foreign currency lending rates and large-value foreign currency deposit rates started to be removed in 2000. As for domestic currency transactions, a corridor was established in 1996 for RMB loans, which was gradually widened until the upper limit was lifted in October 2004, except for credit cooperatives. In 1999, interest rates on long-term large-value RMB deposits started to be liberalized on a gradual basis. In October 2004, the lower limit on the interest rate of all RMB deposits was lifted but not the upper limit (Table A8 in Appendix 1 offers additional details on interest rate liberalization). The $\mathrm{PBC}$ has announced additional measures, such as eliminating the upper limit on RMB loans for credit cooperatives and abolishing the existing lower limit on lending rates for all institutions; it also intends to eliminate the upper limit for all RMB deposits and liberalize interest rates on remaining foreign currency deposits (smallvalue with maturity less than 1 year) at some point in time. In this context, the $\mathrm{PBC}$ has also announced the introduction of market-based monetary policy instruments.

In the current setting, the liberalization of the ceiling on the lending rate and of the floor on the deposit rate implies no limit as to how large the spread between the lending and deposit rate, but a clear one on how small it can be, i.e. the difference between the reference lending and deposit rates. This difference hovered at 330 basis points (Figure 8) until 


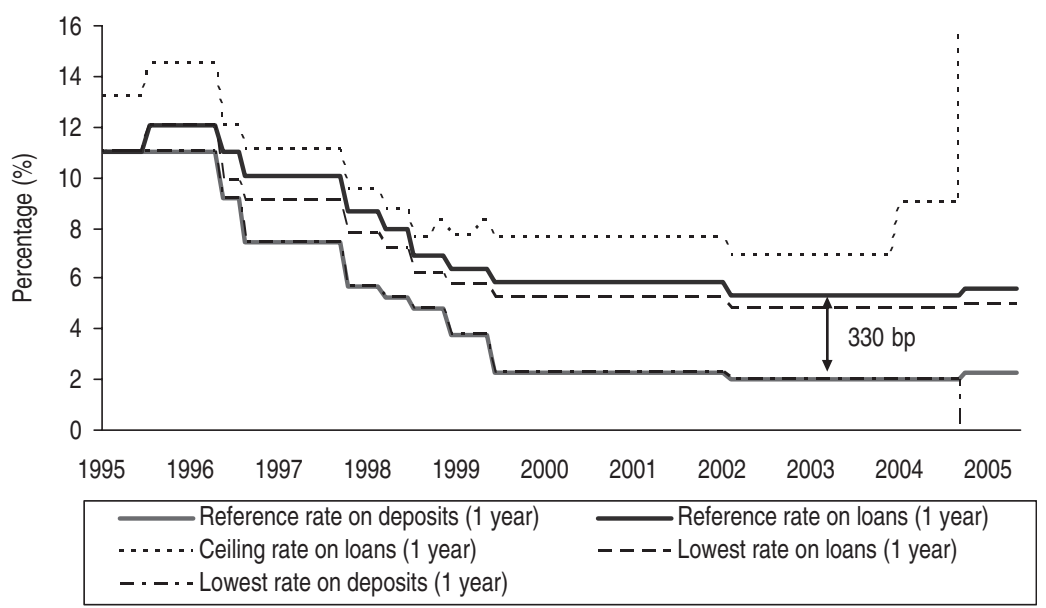

Source: CEIC

Figure 8 Lending and deposit rates

April 2006, when was widened in 27 basic points, and offers a safe margin for banks to maintain a relatively high net interest margin.

At the same time, nominal lending and deposit rates have fallen substantially in the last few years together with real lending rates, which had reached relatively high levels in the first compasses of the reform, as double-digit inflation was being controlled. In late 2004, real lending rates have started to increase again, as a consequence of a more restrictive monetary policy stance, but still remain relatively low, well below 4 percent (Figure 9).

\section{Opening up to foreign competition}

A crucial milestone in the financial liberalization process was the conclusion of the negotiations for China's accession to the World Trade Organization (WTO) in late 2001. The commitments agreed under WTO imply the full opening up of the Chinese banking system to foreign affiliates by the end of 2006, but the approach followed has been very gradual and cautious. At the beginning, foreign banks were only allowed to carry out foreign-currency transactions. As a second step, foreign banks were authorized to offer local currency services to foreign enterprises and individuals, albeit with geographical restrictions (starting with the richest regions ${ }^{13}$ ), high minimum capital requirements and tight

13 In Shanghai and Shenzhen, as special economic areas, interest rates were liberalized for foreign companies and individuals even before becoming a WTO member, in 1996. 
A. García-Herrero et al.

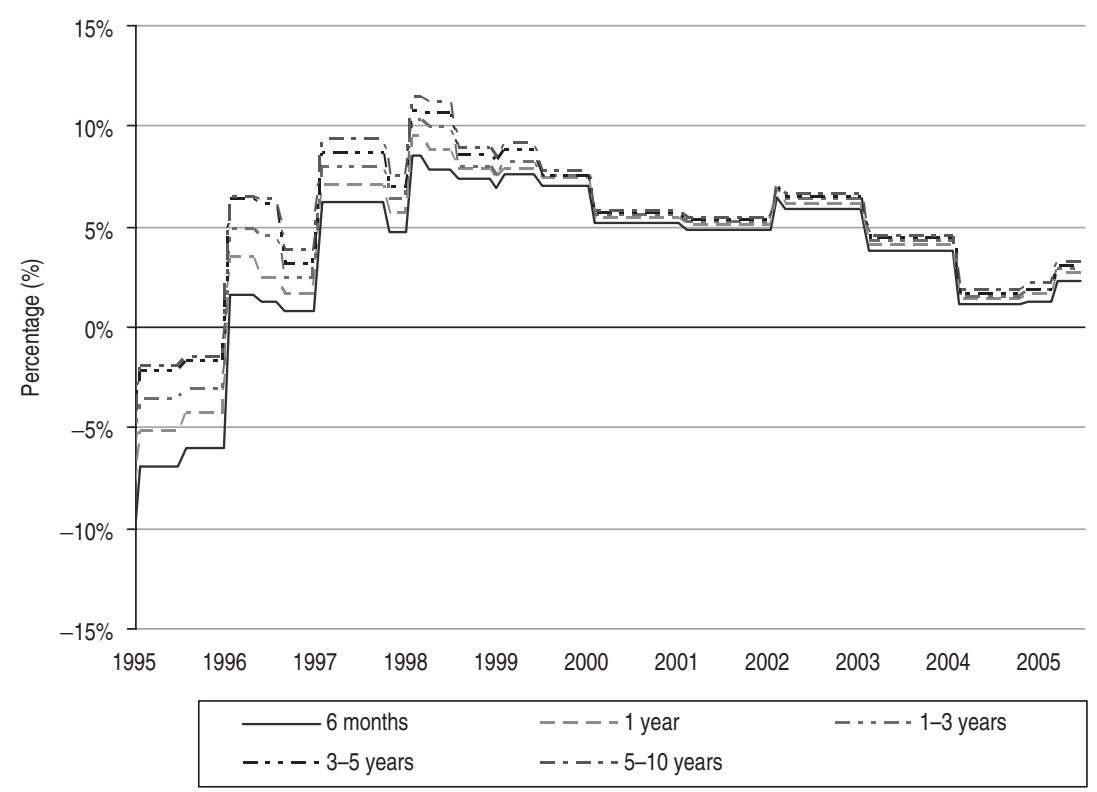

Source: CEIC

Figure 9 Real interest rates on loans (reference)

prudential norms, compared with international standards (Table 3). Third, in 2003, the wholesale market in domestic currency (i.e. to Chinese enterprises) was opened to foreign competition for a relatively large number of provinces. Finally, from the end of 2006 onwards, foreign banks will be able to offer all banking services in local currency in all provinces and even to Chinese households. In addition, the Chinese authorities have recently announced measures to facilitate the entry of foreign affiliates, such as lifting the ban to open more than one branch per year and reducing minimum set-up capital requirements for the establishment of new branch. Since the signing of WTO in 2001, foreign bank branches have increased from 157 to 192 in 2004, most of which from the Asian origin (mostly Taiwan, South Korea and Hong Kong). The number of representative offices also rose from 184 in 2001 to 223 in 2004.

Although WTO commitments do not deal directly with a foreign acquisition of a stake from a Chinese bank, Chinese authorities have increased the limit on the bank's foreign ownership from 15 to 20 percent of the total capital for one single investor, and to 25 percent for the joint participation of all foreign investors, although this latter ceiling does not 
Table 3 Timetable for opening the financial sector under WTO commitments

\begin{tabular}{|c|c|c|c|}
\hline \multirow[b]{2}{*}{ By geography } & \multicolumn{3}{|c|}{ Foreign banks can begin to offer services in domestic currency to } \\
\hline & $\begin{array}{l}\text { Foreign companies and } \\
\text { foreign individuals }\end{array}$ & Chinese domestic companies & Chinese individuals \\
\hline Open Shanghai, Shenzen & 1996 & 2003 & 2006 \\
\hline Open Tianjing, Dalian & 2001 & 2003 & 2006 \\
\hline Open Guangzho, Qingdao, Nanjing, Wuhan & 2002 & 2003 & 2006 \\
\hline Open Jinan, Fuzhou, Chengdu, Chongqing & 2003 & 2003 & 2006 \\
\hline Open Kunming, Zhuhai, Beijing, Amoy & 2004 & 2004 & 2006 \\
\hline Open Swatow, Ningbo, Shenyang, Xian & 2005 & 2005 & 2006 \\
\hline Lift all geographical restrictions & 2006 & 2006 & 2006 \\
\hline
\end{tabular}

Source: WTO and Deutsche Bank Reasearch (2004).

Banking services in foreign currency were liberalized in all regions immediately after WTO accession. 
seem to be applied in listed banks. This reflects the general perception that the system needs fresh capital and highly qualified bank management. As of October 2005, seventeen foreign banks have already entered the capital of Chinese banks and their share in the banks' capital - albeit low-is increasing (CBRC, 2005). Finally, in October 2005, one of the four SOCBs, the CCB made an initial public offering for USD 9.2 billion. According to Ma (2006), by late 2005 the total declared foreign direct investment (FDI) in Chinese banks reached USD 16.5 billion, representing some 15 percent of the banking sector's core capital. Table A9 in Appendix 1 offers a list of the purchases by foreigners and their capital share.

\section{Capital account liberalization}

Capital account liberalization has been even more gradual and remains more incomplete than the rest of the liberalization process. Although more details are offered in Tables A10 and A11 in Appendix 1, the situation, in a nutshell, is that capital inflows are much more liberalized than outflows. FDI abroad, portfolio outflows and even the repayment of credit operations need to be authorized by the State Administration of Foreign Exchange (SAFE). This, together with the fact that resident transactions in foreign currency are strongly regulated, explains why Chinese institutions, including banks, have limited foreign exchange positions although they appear to have increased very fast in the last few years, above 50 percent on average (Table 4). Nonetheless, in May 2006, Chinese residents have been allowed to invest in foreign financial markets through Chinese banks. Banks are long in foreign currency, with net foreign assets equivalent to 6.1 percent of GDP in 2003, while corporates are short, with net foreign liabilities equivalent to 10.8 percent in $2003 .{ }^{14}$

\subsection{Regulation and supervision}

The liberalization and restructuring measures have been accompanied by improvements in regulation. In 1995, together with the assignment to the $\mathrm{PBC}$ of its main objectives, capital adequacy requirements were introduced in all commercial banks, as well as prudential ratios, namely loan to deposit ones and assets to liquid liabilities. These prudential ratios, however, were a formality. In 2002, the PBC, still the Chinese regulator until 2003, established the international five-tier loan classification although it was not made fully compulsory. The reasons for this weak

14 Households can only be long since they can deposit money in foreign currency but not borrow. There is a global limit for the households' deposits in foreign currency, namely 5 percent of the total deposits. 
Table 4 China: Foreign currency exposures of financial and corporate sectors

\begin{tabular}{|c|c|c|c|}
\hline & \multicolumn{3}{|c|}{ (USD billions) } \\
\hline & 2001 & 2002 & 2003 \\
\hline $\begin{array}{l}\text { Net foreign exchange-denominated assets } \\
\text { of the banking system }{ }^{\mathrm{a}}\end{array}$ & 31 & 60 & 57 \\
\hline Of which, net foreign assets & 85 & 108 & 85 \\
\hline (in percent of GDP) & 7.3 & 8.5 & 6.1 \\
\hline Net domestic foreign currency assets & -54 & -48 & -19 \\
\hline Banks' foreign currency loans to domestic residents & 81 & 103 & 130 \\
\hline (in percent of GDP) & 6.9 & 8.1 & 9.2 \\
\hline Net foreign currency exposure of corporate sector & -103 & -121 & -150 \\
\hline Corporates' foreign currency assets ${ }^{\mathrm{b}}$ & 45 & 52 & 52 \\
\hline Corporates' foreign currency liabilities ${ }^{\mathrm{c}}$ & 149 & 172 & 202 \\
\hline Total external debt & 170 & 171 & 194 \\
\hline Of which: short-term & 44 & 48 & 73 \\
\hline Of which: Corporate & 68 & 70 & 82 \\
\hline
\end{tabular}

${ }^{\mathrm{a}} \mathrm{Sum}$ of net foreign assets (net claims against foreign residents) and net foreign currencydenominated assets against domestic residents.

${ }^{\mathrm{b}}$ The estimates are based on corporate foreign currency deposits in domestic banks.

${ }^{\mathrm{c}}$ Sum of corporate external debt and domestic foreign currency loans.

Source: Prasad et al. (2005).

situation were the PBC's lack of sanctioning power and the decentralized nature of its regulatory and supervisory functions. In fact, the bulk of the work was conducted by the local offices, which themselves had to report to the local government.

With the establishment of the CBRC in 2003, there were several improvements. These can be divided into asset quality, capital adequacy and general supervisory matters.

On asset quality, the five-tier loan classification system was enhanced and made fully compulsory for all the banks by the end of 2005. In the same vein, full provisioning of the NPLs will need to be introduced by the end of 2008. In 2005, the CBRC adopted three new tools to strengthen the monitoring of the banks' NPLs, namely making peer group comparison, assessing the deviation of the accuracy of loan classifications and tracking the migration of loans of different categories. Finally, since the early 2006, related party lending has been limited, which is quite important given the concentration of lending in the corporate sector and, in many cases, large SOEs.

On capital adequacy, after an evaluation of the compliance with the Basel Core Principles for Effective Banking Supervision, the 8 percent 
minimum capital adequacy ratio, defined in Basel I terms, was introduced and a 4 percent minimum total capital. These ratios will need to be fully complied with by 2007 . Moreover, bank regulation has adopted a risk-based framework, with guidelines for credit risk, market risk and operational risk. In addition, a CAMEL ${ }^{15}$-type risk assessment system has been introduced with quantitative and qualitative criteria for capital, asset quality, management competence, liquidity and profitability. For the time being, however, this system is being applied only to JSCBs.

Finally, enforcement has begun to be taken into consideration since some sanctions have been imposed. The latter has been facilitated by the introduction of legal protection for supervisors, which they previously lacked. In addition, the CBRC has embarked on a large-scope programme of capacity building, necessary to conduct on-site and off-site inspections.

Efforts have also been made to improve bank corporate governance, through the creation of shareholder boards with outside directors but this is only a very small step, as shall be explained later. Finally, there is now some disclosure of information, particularly for listed banks, which must go through an auditing process as well as the publication of more comprehensive balance sheets and income statements. The CBRC, itself, is enhancing its transparency through the publication of individual bank data, including NPLs.

\section{An assessment of the banking reform so far and potential impact}

From the aforementioned information, there is no doubt about the commitment of the Chinese authorities to bank reform and the measures taken seem to go in the right direction. However, these measures do not seem to be comprehensive enough and several important ones are missing, particularly as regards the incentive structure. The results in terms of bank performance are relatively good in some aspects, such as asset quality for the restructured SOCBs, but not in others, as we shall explain.

\subsection{Bank restructuring}

So far, the restructuring process has managed to improve asset quality but the results seem to be weaker in terms of capitalization. The solvency ratio, calculated according to Basel I, was only 6.73 percent $^{16}$ in 2003 and the ratio of equity to assets remained at similar levels than before the

\footnotetext{
15 CAMEl is the acronym Capital adequacy, Asset quality, Mangement, Earnings, Liquidity and Sensitivity to market risks.

16 Due to data limitations, this ratio has been calculated for the four SOCBs, except for the $\mathrm{ABC}$, and ten of the twelve JSCBs.
} 
reform started (namely 4.3 percent in 2003). The capital injections carried out by the government in 1998 (USD 33 million) had an immediate positive impact on the ratio equity to assets of the banking system (from 4.54 percent in 1997 to 6.03 percent in 1998), but this ratio fell again even below the 1997 levels. This is because, in the second restructuring wave, most of the capital injection was directed to improving asset quality and the third wave has involved relatively few funds. In addition, there has been very little private or public capital raised otherwise. In 2004, however, the situation has improved for the restructured SOCBs (data not available yet for the whole banking system).

The $\mathrm{CCB}$ and the $\mathrm{BoC}$ have received enough public funds to maintain adequate solvency levels; measured in Basel I terms (Figure 10). Instead, the ICB and, much more so, The Agricultural Bank of China (ABC) still suffer from much poorer solvency, higher NPLs and very low provisioning ratios, both in ratios and levels. We have estimated the capitalization needs of these two SOCBs, so as to reach the solvency and asset quality targeted by the Chinese authorities for 2005. These amount to USD 150 billion (or the equivalent of 9.7 percent of 2004 GDP), if we assume the same recovery rate for the NPLs as that obtained by AMCs for the other two restructured SOCBs (Tables A12 and A13 in Appendix 1). ${ }^{17}$ Another point to take into account is that the capital injected into SOCBs in the second and third wave is in USD, which implies an exchange rate risk, particularly considering the larger probability of an RMB appreciation. In fact, the recent 2.1 percent revaluation led to a loss of RMB 9.8 billion.

As for the asset quality, the three waves of restructuring have reduced NPLs in three of the four SOCBs (Table 1 and A7 in Appendix 1). This welcome development, though, needs to be seen in the context of a very rapid loan growth. In fact, apart from the government injections, the improvement in asset quality is mainly explained by the increase in the denominator (bank loans), as shown in Figure 11.

The problem is that there are reasons to think that these new loans may end up into NPLs. First, the criteria for granting loans have not changed substantially, as banks' ownership structure is virtually the same and the reform of SOEs still has a long way to go. Second, the reported NPL ratio for loans extended after 2000 is only 2.5 percent, dramatically lower than the NPL ratio for older loans. Third, the slow-down of the economyparticularly if abrupt-would convert many loans in bad ones. Fourth, the total amount of NPLs in the financial system (i.e. counting what

17 This is within the estimates provided by Standard and Poors (2004) of USD 110-190 billion. 
A. García-Herrero et al.
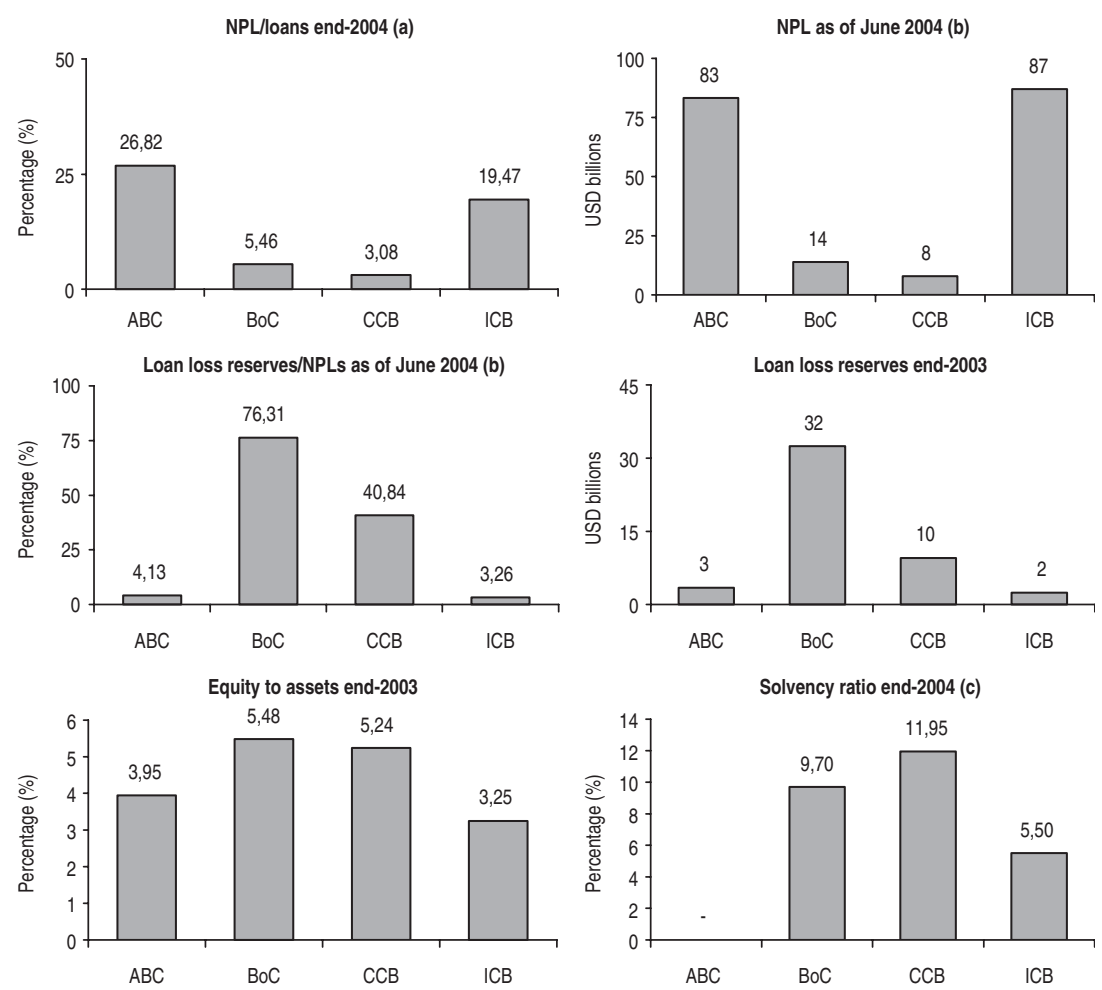

(a) BoC and CCB figures as of June 2004; (b) ABC figures as of end-2003; (c) ICB figures as of end-2003. Source: Bankscope, CBRC and Fitch.

Figure 10 Assets quality, provisions and solvency on SOCBs

has been transferred to the AMCs and not yet recovered) has not fallen much since AMCs have disposed of only half of the NPLs transferred. The latter is due to several factors: first, the incentive structure of AMCs, which are evaluated in terms of the recovery value and not so much the speed at which assets are disposed of or recovered; second, the poor legal framework under which they operate; third, the lack of market instruments to dispose of NPLs. An additional concern is that only the best assets have been sold, which raises doubts about the recovery capacity of AMCs in the medium term and the costs for the Chinese authorities. Finally, the way in which the asset disposal has been designed raises concerns for SOCBs profitability and, eventually, even solvency. This is because AMCs - which are formally independent institutions-have purchased NPLs either at face value or at a 50 percent while they are obtaining a much lower recovery rate. If government support to AMCs 


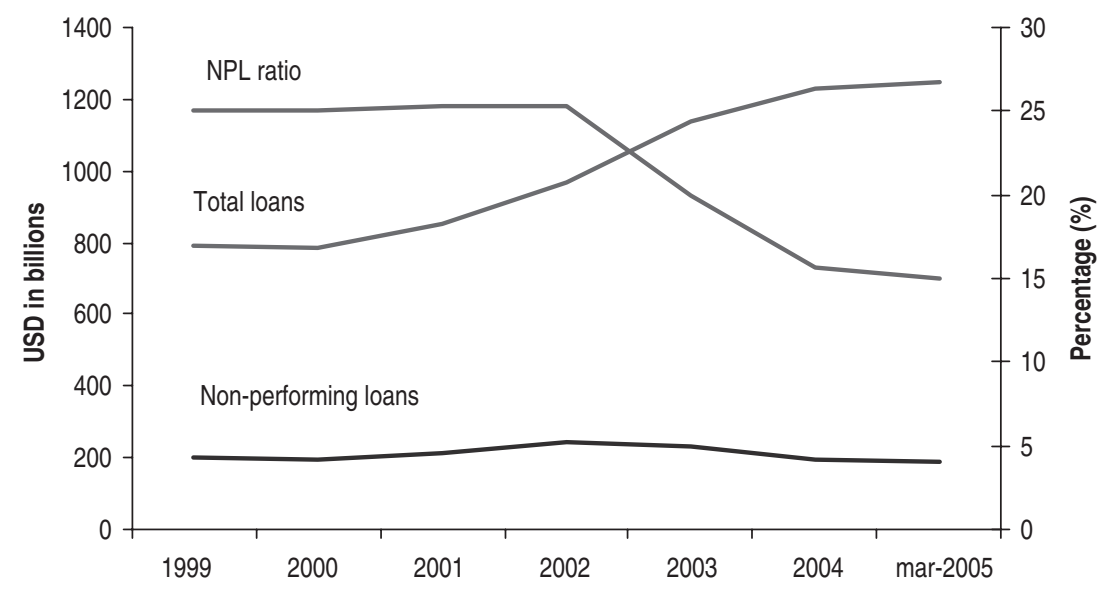

Source: CEIC

Figure 11 Non-performing loans on SOCBs

were not to materialize, these agencies will find it virtually impossible to pay for the principal of the bonds now at SOCBs' balance sheets. Even the payments of the interest coupon - which are anyhow low-are doubtful. ${ }^{18}$ This support, however, should eventually exist, since the whole reform process would be derailed otherwise.

\subsection{Liberalization process}

Although government interference has been reduced with the liberalization process, it is still very large compared with the international standards. The share of SOCBs has fallen and that of JSCBs has risen, but even the latter are only partially privatized. ${ }^{19}$ Furthermore, foreign participation is still very limited in most JSCBs.

Competition is still weak, particularly among the largest banks. This is due to several factors. First the price and quantity controls have not been fully lifted and the opening up to foreign competition has proceeded very cautiously. Foreign competition is limited to the wholesale business and in few areas. The full opening up, following WTO commitments, at the end of 2006 will change the picture only slightly; the country's huge size will make it difficult for banks to compete through Greenfield

\footnotetext{
18 Reportedly, not all interests on these AMC bonds have been paid to SOCBs.

19 According to the $\mathrm{CBRC}$, the largest private share is 80 per cent for the case of China Minsheng.
} 
investment and direct participation in Chinese banks, although it has been fostered, remains limited. In fact, the announcement that SOCBs will be listed does not mean that foreign investors will be offered control. Second, the fast economic growth and, in particular the high investment rate, implies that there is an enormous amount of projects which need to be financed. Thus, there is room for all the banks to make business. Third, the current upper limit on the deposit rate limits competition for deposits, particularly those highly sensitive to the return obtained. Finally, the excessive liquidity of the banking system inhibits competition, so even the programmed full liberalization of the deposit rate might not increase competition in this setting.

Regarding capital account liberalization, the relatively small percentage of the banks' foreign exchange transaction limits, for the time being, the risks related to sharp exchange rate swings. However, the fast increase in exposure in the last few years clearly hints at growing risks as economic openness and capital account liberalization proceed. This is even more the case if we consider that hedging instruments are limited; Chinese banks are not used to managing foreign exchange risk; and the regulator has still not developed strict prudential tools for foreign exchange risk. Furthermore, the fixed exchange regime may be understood as an implicit guarantee, inducing moral hazard and thus, a further build-up of risks, as has happened in other countries.

\subsection{Regulation and supervision}

Efforts have been huge given the starting conditions of Chinese regulatory authorities. However, it is not completely clear how China is going to ensure a level playing field to all the banks. For example, there are questions as to how the regulation imposing a minimum capital adequacy ratio of 8 percent for all commercial banks will be enforced by the end of 2007, as programmed. We cannot expect ABC, credit cooperatives and even some JSCBs to comply with it by that date unless they receive very large capital injections. As previously mentioned, for the remaining two SOCBs, our estimate is USD 150 billion and that of credit cooperatives and CCBs could hover around USD 12 billion (around 9 billion for the former and 3 billion for the latter). As for JSCBs, we estimate at least USD 19 billion to reach a capital to assets ratio similar to that of the $\mathrm{BoC}$ and the $\mathrm{CCB}$, namely 6 percent (details on this estimate can be found in Table A12 in Appendix 1).

One of the main objectives of strengthening regulation and supervision was the introduction of a more cautious approach towards risk. Although it is difficult to draw conclusions from the available evidence, there are two facts which can hardly be reconciled with an improvement in risk 
management. First, loan pricing by SOCBs does not seem to have changed (Podpiera 2006), despite the additional space provided by the liberalization of interest rates. Most loans are still contracted at, or even below, the PBC's benchmark rate. Second, bank lending has continued to grow rapidly (even if it has decelerated somewhat) and there has not been a substantial change in the sector composition: as previously shown in Figure 3, lending for infrastructure projects has continued to grow at much faster rates than consumer lending or mortgages. Moreover, the attempts to improve corporate governance have not shown clear results yet. The recently created shareholder boards are still a formality and the practically full state-ownership biases the decisions taken by bank managers. Finally, Chinese banks are ill-equipped to adopt Basel II - even the second and third pillar as announced by the Chinese authorities - as they are still struggling to adopt Basel I. The large share of low-rated corporate bonds in their balance sheets will increase their need for additional capital under Basel II. In addition, operational risk will probably be large because of poor internal controls.

\subsection{General assessment of bank performance}

In the years in which the reform has been ongoing, overall bank performance has not clearly improved. This is also the case of JSCBs, considered some kind of laboratory of the reform because of their partial private ownership and market orientation, relative to SOCBs.

As already mentioned, the most promising developments come from asset quality but credit growth explains a good part of it. ${ }^{20}$ Another good signal is growing provisioning, although a large part comes from the government recapitalization programmes and is still insufficient to cover NPLs (Figure 12). Developments in solvency have been less encouraging: the capital to asset ratio for the banking system as a whole has remained practically unchanged since the beginning of the reform (Figure 13). The JSCBs have reduced their capital to asset ratios, which is even more worrisome if we consider that they have relatively little Tier II capital. ${ }^{21}$ The reason behind this worrisome trend is the fast asset growth (nearly three times faster than the average) without recourse to additional capital.

Finally, from the already low levels, profitability, measured in terms of ROE, has generally declined. This is also the case for JSCBs (Figure 14).

\footnotetext{
20 In an empirical exercise with bank panel data, García-Herrero, Gavilá and Santabárbara (2006) find that bank size, measured in terms of assets, tends to increase the NPL ratio.

21 The issuance of subordinated debt has been stepped up in 2004-2005.
} 
A. García-Herrero et al.

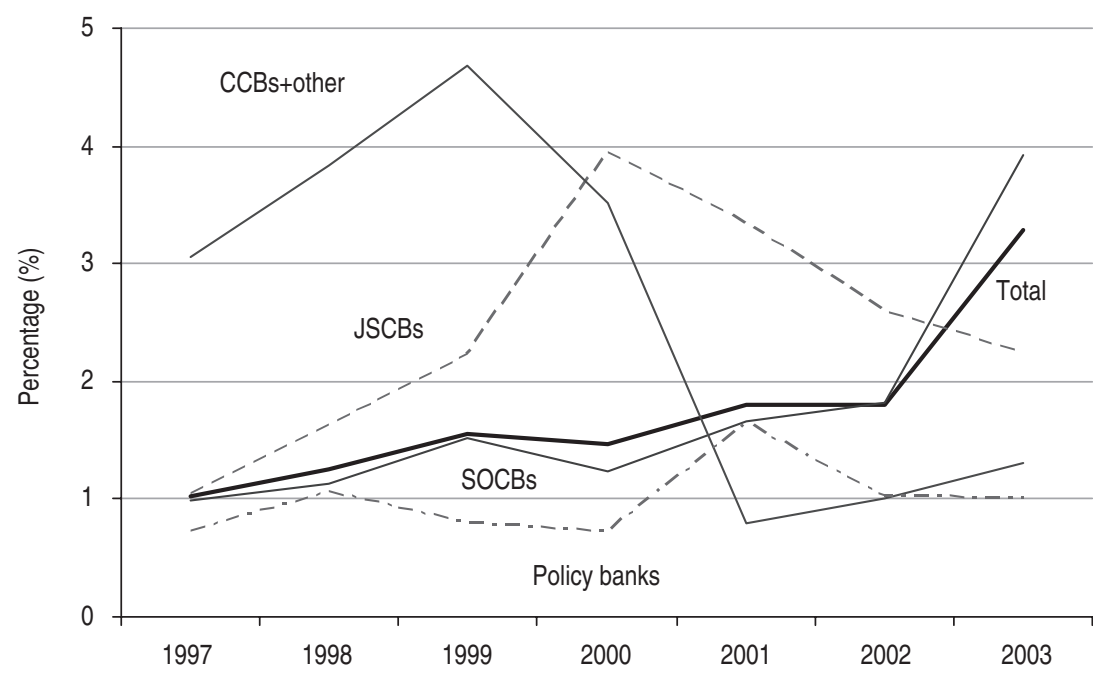

Source: Bankscope

Figure 12 Percent change in loan loss reserve to gross loans by type of institution

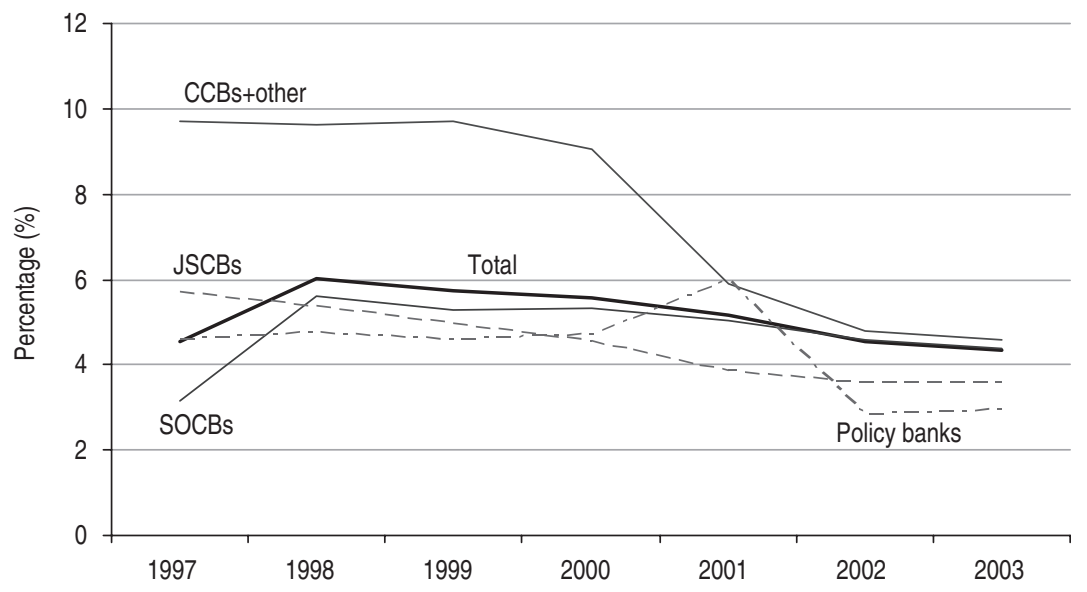

Source: Bankscope

Figure 13 Equity to assets

There are some welcome reasons to explain the fall in profitability, namely declining inflation and real interest rates as well as provisioning, which have been found important determinants of profitability in an empirical analysis for Chinese banks (García-Herrero, Gavilá and 


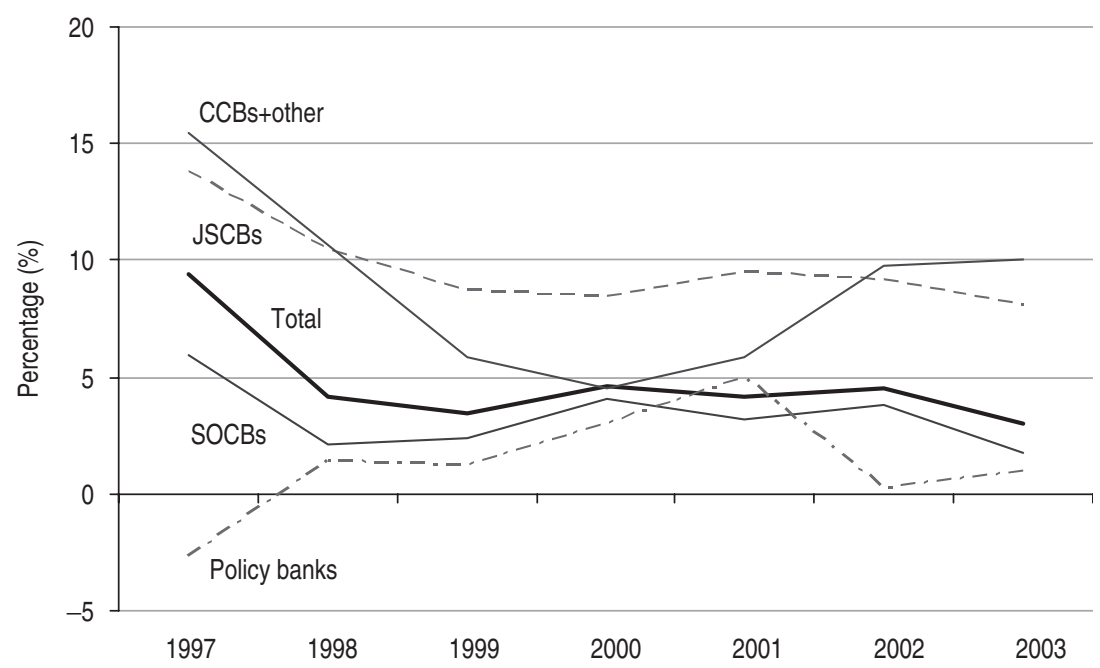

Source: Bankscope

Figure 14 Return on equity (ROE)

Santabárbara 2006). In the case of JSCBs, ROE has fallen, notwithstanding their low capital to asset ratio and their relatively low cost to income ratio, ${ }^{22}$ because they have experienced a reduction in interest income to achieve a higher market share. Figure A3 in Appendix 1 show which are the main factors behind the declining trend of ROA.

In sum, the reform on the Chinese banking system has not brought sizeable benefits so far except for asset quality, and doubts remain about a possible build-up of new NPLs given the fast credit growth. This poor assessment is valid not only for SOCBs, but also for JSCBs, and for the banking system as a whole. In the case of JSCBs, the poor performance might be due to the very limited private control of these banks or, on a more optimistic tone, because it is too early to feel the benefits. However, it could also be the case that the steps taken have not been bold enough and more aggressive measures are needed to change the course of events.

22 García-Herrero, Gavilá and Santabárbara (2006) also find that capitalization and efficiency are significant determinants of the ROA. 


\section{Suggestions for future steps}

\subsection{An accelerated and more comprehensive reform strategy}

Although the Chinese reform is going in the right direction, we argue that it should be accelerated and made more comprehensive. We offer three main reasons for this. First, the challenges that the Chinese economy faces are pressing, in terms of huge financing needs for such a dynamic economy and the commitment to open up to foreign competition by the end of 2006 . Second, opportunities are also large, since China is considered to have a very attractive economy and foreign investors' interest is enormous. Third, the costs of restructuring are bound to increase as time goes by. This is because SOEs - which are at the core of the NPL problem-will generally continue to accumulate losses unless restructured or closed and therefore the flow of NPLs will continue. Finally, the reform, so far, has not managed to improve banks' performance to an extent that we can be sure that the process will not be derailed. The main risk in this regard is the huge pile-up of new loans, some of which could become nonperforming in the future, particularly if the economy decelerates.

The main objectives of this comprehensive reform should be: (i) raising asset quality and solvency to international levels, as soon as possible, and maintaining them, notwithstanding the very fast growth of credit; (ii) transforming existing banks into viable, financially sound and independent commercial institutions. The former requires a complete restructuring, coupled with improved corporate culture, risk management, supervision and, possibly a change in the ownership structure. For the latter, apart from better corporate governance, complete financial liberalization is needed so that banks learn to take decisions on their own and to manage risk. Finally, this second objective should also imply choosing a model for the Chinese banking system, in terms of institutional functioning, size, structure and ownership.

\subsection{On bank restructuring}

The authorities seem to have embarked in the restructuring process without a clear diagnosis of the underlying causes of the problem. Or, if such diagnosis exists, it has not been considered with the highest priority. It seems undeniable that government interference is behind the huge accumulation of NPLs. To solve the problem, two things seem crucial: first the completion of the restructuring of SOEs is needed at the fastest speed possible; second, bold decisions are needed to improve corporate governance and to reduce government control in the banking system. Good corporate governance requires strong in-house capability to price and monitor credit risk, which is a challenge given the scarcity of human capital in Chinese banks and finally, assessing interest and exchange risk 
will become more relevant as financial liberalization moves on. In this regard, the introduction of internal audit and external audit needs to be accelerated and strengthened.

As for the cleaning up of NPLs and the recapitalization of the banking system, the current strategy is too piecemeal and is not time-bound. Chinese authorities should announce a precise timetable with specific deadlines for NPL disposal and recapitalization up to Basel I solvency levels for those banks deemed viable. The sooner the financial system is freed from NPLs, the easier it will be to introduce good corporate governance and risk management. The two, however, should go hand in hand, to avoid using the newly injected capital to grant loans under the same criteria as before. In this regard, the currently very high interest of foreign investors in China should be profited from, since a larger share of foreign competition in the Chinese banking system would be of great benefit to change the incentive structure. The example of Central and Eastern Europe is interesting in this regard since foreign banks were a key restructuring instrument.

Independently, from a change in the ownership structure, the Chinese authorities should take action to solve both the stock and the flow problem. Removing inherited NPLs is important, but even more so freeing banks from inherited bad clients; by nature, banking is a relational business and bad relations are hard to break. A key measure to tackle the flow problem is accelerating SOEs' restructuring. Otherwise, the tight links between SOCBs and SOEs are bound to bring new NPLs. In this regard, the government announcement that SOEs will not be bailed out from 2008 onwards is welcome. Besides, financial liberalization will oblige the banks to evaluate risk and price it properly, instead of taking the official lending rate as given. In this regard, risk management procedures, still at their infancy in China, need to be improved as fast as possible. This obviously requires capacity building at banks, which can be speeded up through the participation of foreign investors in banks' ownership. A new bankruptcy law-whose approval has been delayed in several instances - is also needed, to help restore debt-payment capacity among viable firms and recover NPLs from banks and AMCs.

As for the stock problem, the Chinese model, based on one AMC per $\mathrm{SOCB}$, is probably delaying the resolution of the NPL problem. In fact, in the absence of a monopolistic position, AMCs are obliged to compete offering high recovery values. The fact that their position with large borrowers is not strong probably delays recovery too. Another problem is that the governmental nature of AMCs is not explicit so that they should, at least formally, care for profitability, probably delaying disposal. For the latter, an explicit government guarantee to AMCs would be highly welcome. Finally, fiscal cost considerations should not delay the 
process: the longer it takes to solve the problem, the higher the cost will be. Finally, the transfer of NPLs to solve the stock problem, should be accompanied by enough capital injections to comply with the capital adequacy ratio. This is not only necessary for the soundness of Chinese banks but also probably to improve its profitability (as García-Herrero, Gavilá and Santabárbara 2006 show in an empirical study on the determinants of ROA for Chinese banks). The current approach based on different restructuring waves, and starting with capital injections, does not induce bank managers to strengthen the assessment of risks when granting credit. The easiest way to improve this situation is to link recapitalization to a change in ownership (i.e. privatization). Another, more difficult, possibility is to set stringent rules for provisioning and improving asset quality while forcing a change in corporate governance. Finally, the substitution of NPLs with bonds issued by AMC appears as a good restructuring technique as long as AMCs are solvent or have a clear government guarantee. Otherwise, banks may be facing new problems when these bonds are due, or even before, if AMCs cannot recover enough assets to pay for the annual interests of these bonds.

Regarding privatization, only solvent and viable institutions should be privatized. Otherwise, there is a risk that these banks can never be profitable and that shareholder problems are bounced back to the public sector. Not all privatization methods are equally effective in improving corporate governance. While initial public offerings (IPOs) may be politically attractive, widely held ownership is unlikely to produce the desired improvements in operations, management and controls that a strategic investment by a strong financial institution would deliver. Options to ensure participation by a desirable strategic investor include a sale by tender or an IPO, where a significant percentage is reserved for a pre-qualified investor. The Chinese authorities seem to have followed this path with the $\mathrm{CCB}$, which is welcome but more might be needed in the most difficult cases. This would imply the transfer of the control from the State to the acquirer.

In the Chinese case, it is important to note that controlling interest does not necessarily imply majority ownership. The voting rights on the investors' shares vs. those retained by the government, can be structured in such a way as to convey controlling influence to a minority stakeholder, or explicit agreements can be made as part of the contract that the investor will make appointments to key management and board positions. Finally, even if the State retains control of banks, the same level-playing field needs to be ensured between private (also foreign) and public banks. This will be tackled later in the suggestions for improved regulation and supervision. 


\subsection{On financial liberalization}

China has taken a very cautious approach to liberalization but it faces pressures to accelerate it from several fronts. First, the international community is calling for exchange rate flexibility, which eventually needs to be accompanied by deeper capital account liberalization. ${ }^{23}$ This might bring new opportunities, but also new risks, for the financial system. The major risk that the Chinese authorities perceive is of capital flight, which would imply a sharp drop in the deposits held at Chinese commercial banks. Second, China has committed under the WTO to finalize the opening up of the banking system to foreign competition by 2006. Although this basically refers to greenfield investment (which may take long to acquire a large dimension in China's huge market), it is still an important challenge for China's relatively inefficient banks.

As for the sequencing of liberalization, China has basically gone by the handbook, starting with macroeconomic stabilization, followed by domestic financial liberalization and leaving capital account liberalization as the last step (McKinnon 1982). However, in China's case, the completion of bank restructuring is needed to profit fully from financial liberalization. We see two reasons for this. First, the banks will probably not use correctly the room offered by financial liberalization unless banks' incentive structure changes. In fact, the banks are not using the space they now have to increase the lending rate. In addition, the currently "guaranteed" minimum interest rate spread-because of the floor on the lending rate and the ceiling on the deposit rate - contributes to a rather large interest rate margin which could be reduced with full interest rate liberalization, particularly if competition increases. The potential additional fall in profitability would call for an increase in the currently very low capitalization of the Chinese banking system so as to counteract this trend. ${ }^{24}$

As for the opening up, there is no doubt that foreign capital can help modernize the Chinese banking system, through better corporate governance and risk management, in addition to fresh capital. To achieve this goal, however, its presence cannot be limited to representative offices or branches focused on niche businesses. They should become a real competitive force in the intermediation of domestic savings.

\footnotetext{
23 Prasad, Rumbaugh and Wang (2005) argue that exchange rate flexibilization may come first, but they acknowledge that it needs to be followed up by capital account liberalization.

24 García-Herrero, Gavilá and Santabárbara (2006) find the equity to asset ratio to be a key determinant of profitability.
} 
Given the country's huge size, this can only be achieved, in a reasonably short time, by allowing foreign banks to obtain the control of some Chinese financial institutions, as previously proposed.

Finally, a successful opening of the capital account requires a change in the way monetary and exchange rate policies are conducted. Monetary instruments that impose a high cost or administrative constraint on the banks - as is the case with credit or interest rate ceilings or high nonremunerated reserve requirements - need to be substituted by market instruments.

\subsection{On regulation and supervision}

Although the authorities have moved forward on this front, bolder steps are needed. The main objectives should be: (i) to improve - or at least maintain - asset quality but also solvency and (ii) to ensure a level playing field across different institutions.

For the former, the current regulation on asset quality and solvency should be enforced to all commercial banks and sanctions applied when necessary. The recent major scandals in some SOCBs are a sign of the need for coercion and sanctioning power, so that the experience will not be repeated. In addition, the regulator should encourage a radical change in the banks' incentive structure, through better corporate governance and reducing government intervention. This is clearly the key since, in the current setting, regulators and owners are generally the same. Apart from a change in the ownership structure, the regulator has a role to play by requesting to strengthen the functions of the board of independent directors so that they are clearly charged with fiduciary responsibility for the public funds invested in the bank. Finally, better bank management techniques need to be encouraged as well as a tighter grip on risk management. This should include exchange rate risk, given the country's move towards more exchange rate flexibility and the gradual lifting of foreign exchange controls.

To ensure a level-playing field, banks should have a clear mandate as to what their duties are when operating on a commercial basis. This should include full insulation from political influence and be subject to the same regulatory and supervisory regime. Such a mandate should not only include SOCBs but also possibly, credit cooperatives. Policy banks, as development banks, should also have clear rules that they should abide by. In addition, accounting rules in line with international standards are crucial to ensure a level playing field as well as external and internal auditing. Finally, more disclosure, starting with the regular publication of banks' balance sheets and income statements. 
Other steps towards improving the institutional setting of the banking system need to be taken swiftly, such as a better functioning of the payment system, the creation of a credit register and a limited and explicit deposit insurance system. The recent announcement of a government compensation for individual deposits is welcome, but it could be defined better. Finally, a bankruptcy law, which also deals with financial institutions, needs to be established as soon as possible.

All in all, it seems clear that the announcement of a comprehensive, fast and time-bound reform strategy is urgently needed, where the authorities should clarify their long-term view of the Chinese financial sector and the steps they will take to achieve it, with precise deadlines. For the reform to be comprehensive, a clear definition of responsibilities for each Chinese agency involved would be highly welcome, as well as the nomination of a single coordinator. As for the speed, the current reform process seems too slow for the immediate challenges that China faces, so that it risks being derailed. The strategy should not be that of "growing out of the problem", as could be interpreted from the rapid growth in bank lending. Finally, foreign players should be offered an important role in the process since government intervention is at the origin of the problem and there are not enough private investors in the country having banking experience.

\section{References}

Brandt, L. and H. Li (2003), "Bank discrimination in transition economies: ideology, information, or incentives?", Journal of Comparative Economics 31, 387-413.

Bofit (2004), BOFIT Weekly, January-July, Bank of Finland. (2004). China Review, Vols 1 and 2, May, Bank of Finland.

CBRC (2005), “Latest Developments in China's Banking Reform, Opening-up and Supervision', December.

Chang, C. (2003), "Progress and peril in China's modern economy", Federal Reserve Bank Of Minneapolis, The Region 17, 26-30.

Cull, R and L.C. Xu (2000), "Bureaucrats, state banks, and the efficiency of credit allocation: the experience of Chinese state-owned enterprises", Journal of Comparative Economics 28, 1-31.

Demirgürç-Kunt, A. and E. Detragiache (1998), "Financial liberalization and financial fragility", IMF Working Papers 98/83, International Monetary Fund.

Deutsche Bank Research (2004), China's Financial Sector: Institutional Framework and Main Challenges, January. 
ECB (2004), "EU Banking Sector Stability".

Ernst and Young (2004), "Global NPL Report 2004".

Fitch's Bankscope International Bank Database.

García-Herrero A., and D. Santabarbara (2004), Where is the Chinese Banking System Going with the Ongoing Reform, Documento Ocasional No. 0406, Banco de España.

García-Herero, A., S. Gavilá and D. Santabárbara (2006), What explains the low profitability of Chinese banks? Mimeo.

He, L. and F. Xiaohang (2004), "Foreign banks in post-WTO China: an intermediate assessment", China \& World Economy 12, 3-16.

Karacadag, C. (2003), China: Financial System Soundness and Reform, chapter of the book, China, Competing in the global economy, Washington: IMF.

La Porta, R., F. López-De-Silanes and A. Shleifer (2002), "Government Ownership of Banks", Journal of Finance 57, 265-301.

Ma, G. (2006), Who pays China's bank restructuring bill?, CEPII Working Paper No. 2006-04. February 2006.

Ma, G. and B.S.C. Fung (2002), China's asset management corporations, BIS Working Papers No.115, August.

McKinnon, R. (1982), "The order of economic liberalization: lessons from Chile and Argentina", Carnegie-Rochester Conference Series on Public Policy 17, 159-186.

Moreno, R. (2002), Reforming China's Banking System, FRBSF Economic Letter No. 2002-17, May 31.

OECD (2002). "China in the world economy. The domestic policy challenges." OECD, Paris.

Park, A. and K. Sehrt (2001), "Tests of financial intermediation and banking reform in China", Journal of Comparative Economics 29, 608-644.

Pei, G., and S. Shirai (2004), The Main Problems of China's Financial Industry and Asset Management Companies, February.

People's Bank of China (2005), China Monetary Report.

Ping, L. (2003), Challenges for China's banking sector and policy responses, Speech in New Delhi, November.

Podpiera, R. (2006), Progress in China's banking sector reform: has bank bevaviour changed?, IMF Working Paper No. 06/71.

Prasad, E., T. Rumbaugh and Q. Wang (2005), Putting the Cart Before the Horse? Capital Account Liberalization and Exchange Rate Flexibility in China, IMF Policy Discussion Paper. 
Roubini N. and B. Setser (2005), "China Trip Report", April.

Sapienza, P. (2004), "The effects of government ownership on bank lending", Journal of Financial Economics 72.

Standard \& Poor's (2004), “China's Banks Face Potential Stress in Loan Books".

Wei, S.J. and T. Wang (1997), "The Siamese twins: do state-owned banks favor state-owned enterprises in China?", China Economic Review 8, 19-29.

Wilson, D. and R. Purushothaman (2003), Dreaming with the BRICS, Goldman Sachs, p. 2.

Zhou, X. (2004), Some issues concerning the reform of the state-owned commercial banks, Speech by the Governor of the People's Bank of China, at the IIF Spring Membership Conference, Shanghai, 16 April. 
A. García-Herrero et al.

\section{Appendix 1: Figures and Tables}

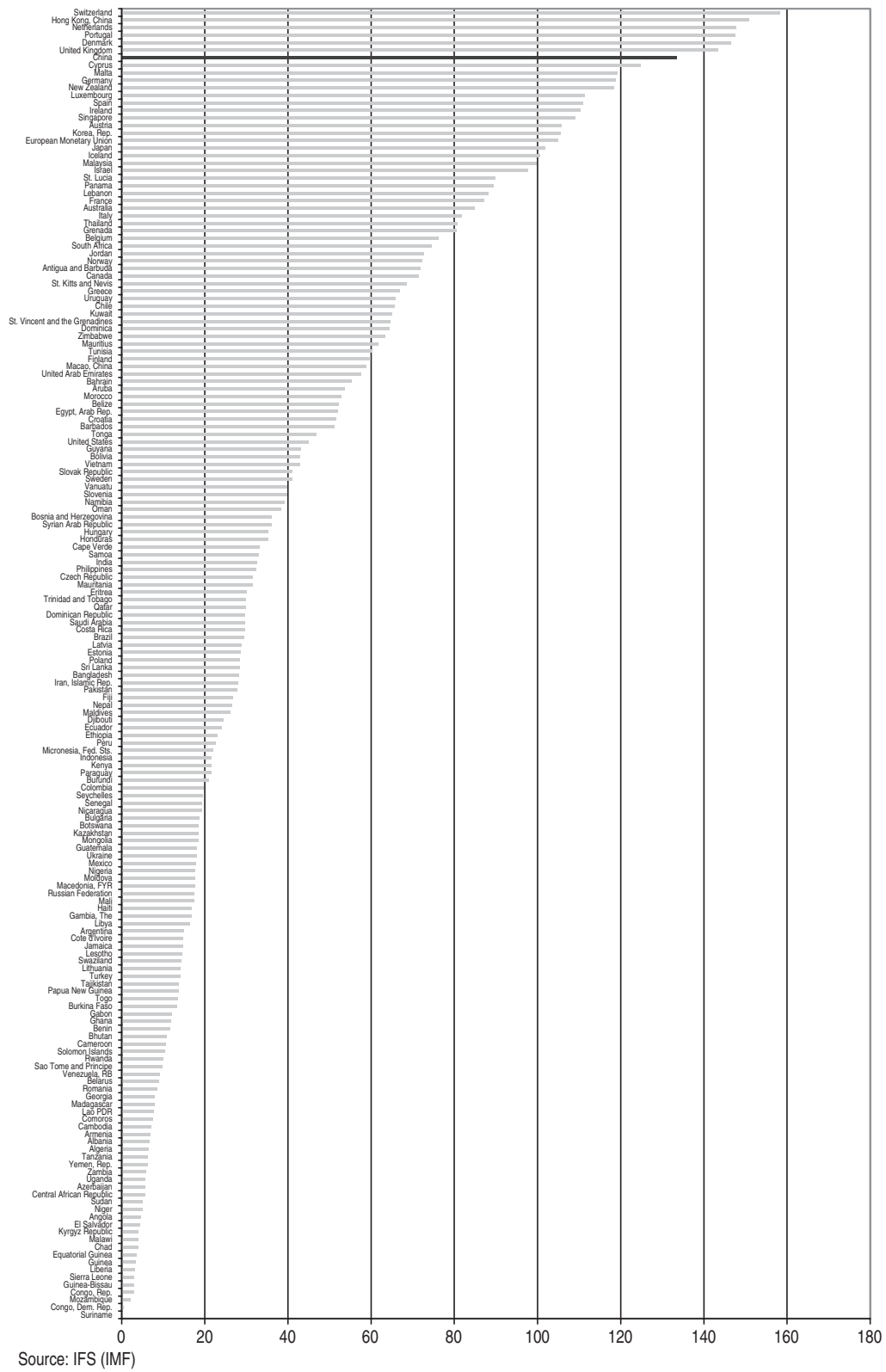

Figure A1 International comparison of bank credit to the private sector, as a percentage of GDP 


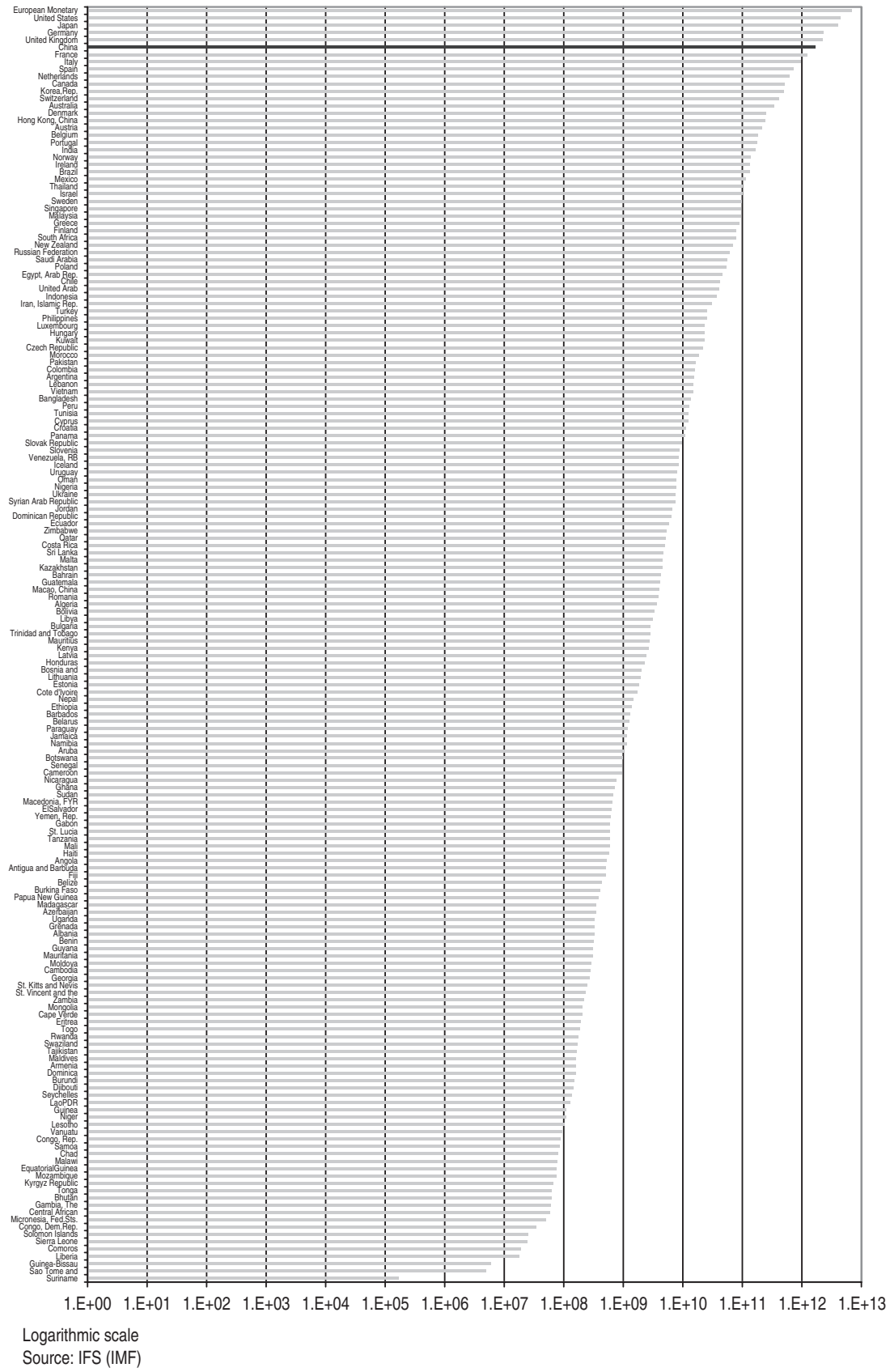

Figure A2 International comparison of bank credit to the private sector, in USD 
A. García-Herrero et al.

Table A1 Share on assets by type of institution

\begin{tabular}{|c|c|c|c|c|c|c|c|c|}
\hline & SOCBs & JSCBs & $\begin{array}{c}\text { Credit } \\
\text { cooperatives }\end{array}$ & $\mathrm{CCBs}$ & $\begin{array}{c}\text { Foreign } \\
\text { funded } \\
\text { banks }\end{array}$ & $\begin{array}{l}\text { Policy } \\
\text { banks }\end{array}$ & $\begin{array}{l}\text { Other } \\
\text { institutions }\end{array}$ & $\begin{array}{r}\text { Total } \\
\text { assets } \\
\text { (USD } \\
\text { billion) }\end{array}$ \\
\hline 1993 & 73.9 & 4.4 & 11.4 & 0.0 & 0.0 & 9.9 & 0.4 & 695 \\
\hline 1994 & 72.1 & 5.4 & 12.9 & 0.0 & 0.0 & 9.2 & 0.5 & 596 \\
\hline 1995 & 69.7 & 6.6 & 14.3 & 0.0 & 0.0 & 8.8 & 0.7 & 770 \\
\hline 1996 & 65.3 & 7.3 & 14.1 & 0.0 & 0.0 & 12.4 & 0.9 & 944 \\
\hline 1997 & 65.8 & 7.1 & 14.2 & 0.0 & 0.0 & 12.0 & 0.9 & 1154 \\
\hline 1998 & 65.1 & 7.5 & 13.5 & 0.0 & 0.0 & 13.0 & 1.0 & 1333 \\
\hline 1999 & 64.9 & 8.1 & 13.3 & 0.0 & 0.0 & 12.8 & 1.0 & 1489 \\
\hline 2000 & 63.9 & 9.6 & 13.1 & 0.0 & 0.0 & 12.3 & 1.0 & 1680 \\
\hline 2001 & 60.5 & 11.3 & 14.1 & 0.0 & 0.0 & 12.8 & 1.3 & 1797 \\
\hline 2002 & 57.9 & 12.8 & 9.9 & 4.9 & 1.2 & 11.4 & 1.7 & 2598 \\
\hline 2003 & 56.1 & 14.0 & 10.1 & 5.3 & 1.2 & 11.5 & 1.8 & 3070 \\
\hline 2004 & 54.6 & 15.0 & 10.4 & 5.4 & 1.6 & 11.4 & 1.5 & 3619 \\
\hline
\end{tabular}

Source: CEIC. 
Table A2 Asset structure of the banking sector

\begin{tabular}{|c|c|c|c|c|c|c|c|}
\hline & \multicolumn{7}{|c|}{ (As a percentage of total assets) } \\
\hline & 1997 & 1998 & 1999 & 2000 & 2001 & 2002 & 2003 \\
\hline Loans & 62.7 & 62.3 & 59.9 & 57.6 & 57.3 & 58.8 & 60.8 \\
\hline State-owned commercial banks & 60.7 & 61.1 & 57.6 & 55.9 & 56.8 & 57.9 & 60.3 \\
\hline Other commercial banks & 48.8 & 48.2 & 47.0 & 47.6 & 53.0 & 55.0 & 58.5 \\
\hline Joint-stock commercial banks & 48.4 & 50.5 & 49.9 & 50.3 & 53.7 & 57.0 & 60.5 \\
\hline Other & 49.5 & 44.6 & 41.5 & 42.0 & 49.5 & 47.5 & 50.5 \\
\hline Policy banks & 93.2 & 89.7 & 92.2 & 89.2 & 81.7 & 93.5 & 92.1 \\
\hline EU-15 & 49.2 & 49.4 & 48.3 & 47.9 & 47.0 & 46.7 & 45.2 \\
\hline Other risky assets ${ }^{\mathrm{a}}$ & 11.1 & 14.7 & 18.1 & 22.1 & 24.6 & 24.7 & 23.7 \\
\hline State-owned commercial banks & 11.4 & 15.2 & 20.3 & 24.3 & 25.2 & 25.9 & 24.9 \\
\hline Other commercial banks & 12.9 & 16.3 & 17.7 & 19.6 & 23.8 & 25.0 & 22.8 \\
\hline Joint-stock commercial banks & 15.9 & 19.2 & 19.1 & 20.9 & 21.9 & 22.1 & 20.6 \\
\hline Other & 8.0 & 11.7 & 15.0 & 17.0 & 32.7 & 36.5 & 31.6 \\
\hline Policy banks & 3.0 & 6.8 & 4.9 & 8.5 & 16.6 & 1.7 & 1.3 \\
\hline EU-15 & 17.5 & 18.3 & 21.2 & 22.4 & 23.4 & 24.1 & 24.8 \\
\hline Liquid assets & 24.2 & 21.1 & 20.0 & 18.3 & 16.0 & 14.6 & 13.7 \\
\hline State-owned commercial banks & 25.7 & 21.6 & 19.9 & 17.7 & 15.9 & 14.2 & 13.1 \\
\hline Other commercial banks & 37.1 & 34.3 & 33.8 & 31.3 & 21.6 & 18.5 & 17.4 \\
\hline Joint-stock commercial banks & 34.4 & 29.0 & 29.3 & 27.3 & 22.8 & 19.6 & 17.6 \\
\hline Other & 41.6 & 42.7 & 42.4 & 39.9 & 15.9 & 14.5 & 16.5 \\
\hline Policy banks & 3.6 & 3.2 & 2.6 & 1.8 & 1.5 & 3.8 & 5.4 \\
\hline EU-15 & 32.1 & 31.1 & 29.4 & 28.7 & 28.6 & 28.2 & 29.0 \\
\hline Fixed assets & 1.9 & 1.8 & 2.0 & 2.0 & 2.0 & 1.9 & 1.7 \\
\hline State-owned commercial banks & 2.2 & 2.0 & 2.1 & 2.1 & 2.1 & 2.0 & 1.7 \\
\hline Other commercial banks & 1.1 & 1.2 & 1.5 & 1.4 & 1.6 & 1.4 & 1.3 \\
\hline Joint-stock commercial banks & 1.2 & 1.3 & 1.7 & 1.6 & 1.5 & 1.4 & 1.3 \\
\hline Other & 1.0 & 1.0 & 1.1 & 1.2 & 1.9 & 1.4 & 1.4 \\
\hline Policy banks & 0.2 & 0.3 & 0.3 & 0.5 & 0.3 & 1.0 & 1.2 \\
\hline EU-15 & 1.2 & 1.2 & 1.1 & 1.1 & 1.0 & 1.0 & 0.9 \\
\hline
\end{tabular}

Source: Bankscope.

${ }^{\mathrm{a}}$ It includes AMC bonds. 
A. García-Herrero et al.

Table A3 Liability structure of the banking sector

\begin{tabular}{|c|c|c|c|c|c|c|c|}
\hline & \multicolumn{7}{|c|}{ (As a percentage of total assets) } \\
\hline & 1997 & 1998 & 1999 & 2000 & 2001 & 2002 & 2003 \\
\hline Deposits \& short-term funding & 83.6 & 82.3 & 81.0 & 83.7 & 83.8 & 89.0 & 89.1 \\
\hline State-owned commercial banks & 89.1 & 88.8 & 89.4 & 90.3 & 90.9 & 91.8 & 92.1 \\
\hline Other commercial banks & 85.6 & 86.3 & 78.0 & 79.2 & 80.9 & 81.8 & 81.7 \\
\hline Joint-stock commercial Banks & 84.6 & 86.1 & 73.7 & 75.6 & 79.0 & 79.7 & 79.9 \\
\hline Other & 87.4 & 86.6 & 86.0 & 86.8 & 89.7 & 89.9 & 88.7 \\
\hline Policy banks & 64.8 & 50.4 & 47.9 & 45.3 & 5.1 & 82.6 & 83.7 \\
\hline EU-15 & 73.0 & 73.0 & 70.9 & 69.3 & 69.2 & 69.5 & 68.2 \\
\hline Other funding & 5.7 & 6.3 & 6.9 & 5.3 & 5.7 & 1.1 & 1.1 \\
\hline State-owned commercial banks & 1.2 & 0.8 & 0.7 & 0.6 & 0.6 & 0.4 & 0.4 \\
\hline Other commercial banks & 1.0 & 0.3 & 0.7 & 0.5 & 0.7 & 0.4 & 0.6 \\
\hline Joint-stock commercial banks & 1.6 & 0.5 & 1.1 & 0.6 & 0.6 & 0.3 & 0.5 \\
\hline Other & 0.1 & 0.0 & 0.1 & 0.2 & 1.0 & 0.9 & 1.2 \\
\hline Policy banks & 27.2 & 38.3 & 43.1 & 46.7 & 84.8 & 11.7 & 12.2 \\
\hline EU-15 & 13.1 & 12.3 & 13.0 & 13.2 & 13.4 & 12.2 & 13.0 \\
\hline Other (Non-interest bearing) & 6.1 & 5.4 & 6.4 & 5.4 & 5.4 & 5.4 & 5.5 \\
\hline State-owned commercial banks & 6.5 & 4.8 & 4.6 & 3.8 & 3.5 & 3.2 & 3.1 \\
\hline Other commercial banks & 6.1 & 6.4 & 14.7 & 14.3 & 14.2 & 14.0 & 13.9 \\
\hline Joint-stock commercial banks & 8.1 & 8.1 & 20.2 & 19.2 & 16.5 & 16.4 & 16.1 \\
\hline Other & 2.9 & 3.7 & 4.2 & 3.9 & 3.5 & 4.5 & 5.5 \\
\hline Policy banks & 3.4 & 6.6 & 4.4 & 3.2 & 4.1 & 2.9 & 1.1 \\
\hline EU-15 & 9.4 & 10.0 & 10.4 & 11.4 & 11.4 & 12.1 & 12.6 \\
\hline Equity & 4.5 & 6.0 & 5.7 & 5.6 & 5.2 & 4.5 & 4.3 \\
\hline State-owned commercial banks & 3.2 & 5.6 & 5.3 & 5.3 & 5.0 & 4.6 & 4.4 \\
\hline Other commercial banks & 7.2 & 7.0 & 6.6 & 6.0 & 4.2 & 3.8 & 3.8 \\
\hline Joint-stock commercial banks & 5.7 & 5.4 & 4.9 & 4.5 & 3.9 & 3.6 & 3.5 \\
\hline Other & 9.7 & 9.6 & 9.7 & 9.1 & 5.9 & 4.8 & 4.6 \\
\hline Policy Banks & 4.6 & 4.7 & 4.6 & 4.7 & 6.0 & 2.8 & 3.0 \\
\hline EU-15 & 4.2 & 4.4 & 4.4 & 4.6 & 4.5 & 4.6 & 4.5 \\
\hline
\end{tabular}

Source: Bankscope. 
Table A4 Sources and uses of bank financing

\begin{tabular}{|c|c|c|c|c|c|c|c|c|}
\hline & \multirow[b]{2}{*}{$\begin{array}{l}\text { Deposits } \\
\text { (USD billion) }\end{array}$} & \multicolumn{7}{|c|}{ Source of deposits (percentage) } \\
\hline & & Enterprise & $\begin{array}{l}\text { Fiscal } \\
\text { deposits }\end{array}$ & Govt. agency & $\begin{array}{l}\text { Household } \\
\text { savings deposits }\end{array}$ & Rural deposits & Trust deposits & Other \\
\hline 1993 & 518 & 29 & 2 & 2 & 51 & 4 & 0 & 12 \\
\hline 1994 & 466 & 33 & 2 & 2 & 53 & 3 & 0 & 7 \\
\hline 1995 & 649 & 32 & 2 & 2 & 55 & 2 & 0 & 7 \\
\hline 1996 & 823 & 33 & 2 & 1 & 56 & 2 & 0 & 6 \\
\hline 1997 & 990 & 35 & 2 & 1 & 56 & 2 & 3 & 1 \\
\hline 1998 & 1156 & 34 & 2 & 1 & 56 & 2 & 3 & 2 \\
\hline 1999 & 1314 & 34 & 2 & 2 & 55 & 2 & 3 & 3 \\
\hline 2000 & 1495 & 36 & 3 & 2 & 52 & 2 & 2 & 3 \\
\hline 2001 & 1735 & 36 & 2 & 2 & 51 & 2 & 2 & 4 \\
\hline 2002 & 2063 & 35 & 2 & 3 & 51 & 2 & 1 & 5 \\
\hline 2003 & 2511 & 35 & 2 & 3 & 50 & 2 & 1 & 6 \\
\hline 2004 & 2905 & 35 & 3 & 3 & 50 & 2 & 1 & 6 \\
\hline
\end{tabular}


Table A4 Continued

\begin{tabular}{|c|c|c|c|c|c|c|c|c|}
\hline & \multirow[b]{2}{*}{$\begin{array}{l}\text { Total loans } \\
\text { (USD billion) }\end{array}$} & \multicolumn{7}{|c|}{ Use of loans (percentage) } \\
\hline & & $\begin{array}{l}\text { Short-term } \\
\text { (ST) }\end{array}$ & $\begin{array}{l}\text { ST: } \\
\text { Industrial }\end{array}$ & $\begin{array}{l}\text { ST: } \\
\text { Commercial }\end{array}$ & $\begin{array}{l}\text { ST: } \\
\text { Construction }\end{array}$ & $\begin{array}{l}\text { ST: } \\
\text { Agricultural }\end{array}$ & $\begin{array}{l}\text { Medium to } \\
\text { long-term }\end{array}$ & Other \\
\hline 1993 & 576 & 74 & 22 & 28 & 3 & 15 & 16 & 11 \\
\hline 1994 & 470 & 67 & 21 & 25 & 3 & 11 & 20 & 13 \\
\hline 1995 & 609 & 59 & 20 & 25 & 2 & 6 & 20 & 21 \\
\hline 1996 & 734 & 66 & 20 & 24 & 3 & 12 & 20 & 14 \\
\hline 1997 & 900 & 74 & 22 & 25 & 2 & 4 & 21 & 2 \\
\hline 1998 & 1045 & 70 & 21 & 23 & 2 & 5 & 24 & 3 \\
\hline 1999 & 1132 & 68 & 19 & 21 & 2 & 5 & 26 & 4 \\
\hline 2000 & 1200 & 66 & 17 & 18 & 2 & 5 & 28 & 3 \\
\hline 2001 & 1357 & 60 & 17 & 17 & 2 & 5 & 35 & 3 \\
\hline 2002 & 1584 & 57 & 15 & 14 & 2 & 5 & 37 & 5 \\
\hline 2003 & 1919 & 53 & 14 & 11 & 2 & 5 & 41 & 6 \\
\hline 2004 & 2142 & 49 & 13 & 10 & 2 & 6 & 43 & 7 \\
\hline \multicolumn{9}{|c|}{ Source: CEIC. } \\
\hline
\end{tabular}


Table A5 Selected indicators for the performance

\begin{tabular}{|c|c|c|c|c|c|c|c|}
\hline & 1997 & 1998 & 1999 & 2000 & 2001 & 2002 & 2003 \\
\hline Return on average assets (ROA) $(\%)$ & 0.43 & 0.22 & 0.20 & 0.26 & 0.23 & 0.22 & 0.14 \\
\hline State-owned commercial banks & 0.19 & 0.09 & 0.13 & 0.22 & 0.16 & 0.18 & 0.08 \\
\hline Other commercial banks & 1.05 & 0.75 & 0.49 & 0.41 & 0.41 & 0.37 & 0.32 \\
\hline Joint-stock commercial banks & 0.78 & 0.58 & 0.45 & 0.40 & 0.39 & 0.34 & 0.29 \\
\hline Other & 1.50 & 1.03 & 0.57 & 0.43 & 0.46 & 0.51 & 0.47 \\
\hline Policy banks & -0.12 & 0.07 & 0.06 & 0.14 & 0.26 & 0.01 & 0.03 \\
\hline Return on average equity (ROE) (\%) & 9.39 & 4.19 & 3.48 & 4.59 & 4.21 & 4.48 & 3.05 \\
\hline State-owned commercial banks & 5.94 & 2.08 & 2.35 & 4.07 & 3.16 & 3.78 & 1.73 \\
\hline Other commercial banks & 14.61 & 10.55 & 7.22 & 6.49 & 8.10 & 9.33 & 8.56 \\
\hline Joint-stock commercial banks & 13.76 & 10.47 & 8.69 & 8.42 & 9.50 & 9.17 & 8.07 \\
\hline Other & 15.42 & 10.62 & 5.86 & 4.54 & 5.86 & 9.81 & 10.00 \\
\hline Policy banks & -2.68 & 1.40 & 1.21 & 2.97 & 4.99 & 0.23 & 1.00 \\
\hline Net interest margin $(\%)$ & 2.03 & 2.07 & 1.90 & 2.22 & 1.93 & 1.95 & 2.03 \\
\hline State-owned commercial banks & 2.40 & 2.47 & 2.07 & 2.35 & 1.98 & 2.02 & 2.11 \\
\hline Other commercial banks & 2.49 & 2.50 & 2.25 & 2.24 & 2.10 & 2.18 & 2.19 \\
\hline Joint-stock commercial banks & 2.38 & 2.57 & 2.20 & 2.30 & 2.32 & 2.21 & 2.27 \\
\hline Other & 2.68 & 2.40 & 2.32 & 2.14 & 1.43 & 2.04 & 1.89 \\
\hline Policy banks & -0.06 & 0.02 & 0.81 & 1.63 & 1.47 & 1.01 & 1.21 \\
\hline Cost to Income Ratio (\%) & 54.51 & 65.40 & 62.22 & 56.61 & 54.51 & 55.52 & 51.68 \\
\hline State-owned commercial banks & 49.31 & 66.33 & 59.16 & 56.18 & 55.52 & 51.76 & 47.87 \\
\hline Other commercial banks & 49.56 & 59.96 & 64.07 & 59.80 & 51.17 & 50.92 & 45.67 \\
\hline Joint-stock commercial banks & 56.05 & 63.13 & 55.33 & 52.24 & 50.48 & 50.64 & 44.71 \\
\hline Other & 38.61 & 54.47 & 77.17 & 75.20 & 54.47 & 52.04 & 49.52 \\
\hline Policy banks & 65.94 & 34.25 & 48.49 & 23.47 & 6.23 & 64.93 & 67.22 \\
\hline
\end{tabular}


Table A5 Continued

\begin{tabular}{|c|c|c|c|c|c|c|c|}
\hline & 1997 & 1998 & 1999 & 2000 & 2001 & 2002 & 2003 \\
\hline Equity/Total Assets (\%) & 4.54 & 6.03 & 5.72 & 5.56 & 5.16 & 4.54 & 4.34 \\
\hline State-owned commercial banks & 3.15 & 5.61 & 5.28 & 5.32 & 5.04 & 4.59 & 4.38 \\
\hline Other commercial banks & 7.20 & 7.01 & 6.60 & 5.99 & 4.22 & 3.81 & 3.76 \\
\hline Joint-stock commercial banks & 5.68 & 5.36 & 4.95 & 4.53 & 3.86 & 3.56 & 3.55 \\
\hline Other & 9.72 & 9.63 & 9.70 & 9.07 & 5.91 & 4.78 & 4.57 \\
\hline Policy banks & 4.60 & 4.73 & 4.59 & 4.72 & 5.98 & 2.81 & 2.95 \\
\hline Capital funds/Liabilities (\%) & 4.76 & 6.41 & 6.07 & 5.89 & 5.44 & 4.76 & 4.55 \\
\hline State-owned commercial banks & 3.26 & 5.94 & 5.57 & 5.62 & 5.31 & 4.81 & 4.58 \\
\hline Other commercial banks & 7.76 & 7.54 & 7.07 & 6.37 & 4.41 & 3.96 & 3.97 \\
\hline Joint-stock commercial banks & 6.02 & 5.66 & 5.20 & 4.75 & 4.01 & 3.69 & 3.77 \\
\hline Other & 10.76 & 10.66 & 10.75 & 9.97 & 6.28 & 5.02 & 4.79 \\
\hline Policy banks & 4.82 & 4.97 & 4.81 & 4.96 & 6.36 & 2.90 & 3.04 \\
\hline Loan loss reserve/gross loans (\%) & 1.03 & 1.26 & 1.55 & 1.46 & 1.81 & 1.81 & 3.30 \\
\hline State-owned commercial banks & 1.00 & 1.12 & 1.52 & 1.24 & 1.66 & 1.82 & 3.91 \\
\hline Other commercial banks & 1.83 & 2.43 & 2.99 & 3.82 & 2.93 & 2.32 & 2.08 \\
\hline Joint-stock commercial banks & 1.05 & 1.63 & 2.23 & 3.94 & 3.35 & 2.60 & 2.24 \\
\hline Other & 3.06 & 3.84 & 4.69 & 3.52 & 0.80 & 1.01 & 1.32 \\
\hline Policy banks & 0.73 & 1.06 & 0.79 & 0.73 & 1.64 & 1.02 & 1.01 \\
\hline $\begin{array}{l}\text { Loan loss provisions } \\
\text { (USD millions) }\end{array}$ & 2.197 & 2.957 & 3.662 & 6.971 & 10.277 & 10.379 & 14.061 \\
\hline State-owned commercial banks & 2.109 & 2.409 & 3.203 & 5.565 & 7.989 & 8.798 & 11.025 \\
\hline Other commercial banks & 74 & 113 & 371 & 756 & 1.008 & 1.582 & 3.036 \\
\hline Joint-stock commercial banks & 74 & 113 & 355 & 715 & 906 & 1.229 & 2.603 \\
\hline Other & 0 & 0 & 15 & 41 & 102 & 353 & 433 \\
\hline Policy banks & 0 & 436 & 89 & 650 & 1.281 & 0 & 0 \\
\hline
\end{tabular}

Source: Bankscope. 
Table A6 Income and expenditure structure of the banking sector

(As a percentage of total income and expenditure, respectively)

\begin{tabular}{|c|c|c|c|c|c|c|c|}
\hline & 1997 & 1998 & 1999 & 2000 & 2001 & 2002 & 2003 \\
\hline Interest income & 90.2 & 91.2 & 90.4 & 91.9 & 90.7 & 87.0 & 87.0 \\
\hline State-owned commercial banks & 96.4 & 96.7 & 95.1 & 95.3 & 93.9 & 91.3 & 91.2 \\
\hline Other commercial banks & 85.4 & 89.4 & 88.8 & 90.6 & 91.6 & 93.0 & 93.0 \\
\hline Joint-stock commercial banks & 81.9 & 86.8 & 89.0 & 90.4 & 91.7 & 94.5 & 94.7 \\
\hline Other & 90.1 & 92.4 & 88.4 & 90.8 & 90.9 & 87.6 & 87.1 \\
\hline Policy banks & 88.2 & 85.8 & 95.4 & 98.4 & 97.7 & 97.5 & 97.5 \\
\hline Commission income & 2.4 & 2.5 & 4.2 & 4.2 & 4.3 & 5.0 & 5.2 \\
\hline State-owned commercial banks & 2.5 & 2.8 & 3.6 & 4.2 & 4.7 & 5.8 & 6 \\
\hline Other commercial banks & 4.5 & 3.6 & 3.9 & 4.2 & 3.7 & 3.9 & 4 \\
\hline Joint-stock commercial banks & 2.5 & 1.9 & 2.5 & 3.1 & 4.1 & 4.3 & 4. \\
\hline Other & 7.2 & 5.5 & 5.7 & 5.7 & 2.4 & 2.5 & 2 . \\
\hline Policy banks & 0.3 & 0.7 & 4.5 & 1.3 & 1.7 & 2.4 & 2 \\
\hline Other income & 7.4 & 6.3 & 5.4 & 3.9 & 5.1 & 8.0 & 7. \\
\hline ned commercial banks & 1.1 & 0.5 & & 0.6 & 1.4 & 2.9 & \\
\hline Other commercial banks & 10.2 & 6.9 & 7.3 & 5.2 & 4.7 & 3.1 & 2 . \\
\hline Joint-stock commercial banks & 15.7 & 11.2 & 8.4 & 6.4 & 4.2 & 1.3 & 0 . \\
\hline Other & 2.6 & 2.1 & 5.9 & 3.5 & 6.8 & 9.9 & 10.3 \\
\hline Policy banks & 11.5 & 13.4 & 0.1 & 0.2 & 0.6 & 0.0 & 0.1 \\
\hline Interest expenditure & 75.9 & 70.8 & 65.7 & 63.4 & 54.3 & 45.4 & 42.0 \\
\hline State-o & 76.4 & 68.6 & 64.9 & 64.4 & 54.5 & 46.0 & 41. \\
\hline Other & 70.7 & 68.5 & 61.8 & 59.4 & 54.3 & 48.5 & 47.5 \\
\hline Joint-stock commercial banks & 64.4 & 59.2 & 59.8 & 55.0 & 53.3 & 47.8 & 45.3 \\
\hline Other & 79.8 & 78.8 & 64.0 & 65.3 & 58.6 & 51.2 & 55. \\
\hline Policy banks & 92.2 & 91.2 & 89.3 & 81.1 & 70.0 & 78.2 & 73.9 \\
\hline Personr & 0.9 & 1.1 & 1.7 & 3.0 & 4.1 & 8.2 & 8. \\
\hline State-owned commercial b & 1.5 & 1.6 & 2.5 & 3.9 & 4.8 & 10.4 & 11.1 \\
\hline Other commercial banks & 0.1 & 0.2 & 0.7 & 0.9 & 3.8 & 4.0 & 4. \\
\hline Joint stock commercial banks & 0.2 & 0.4 & 0.7 & 1.6 & 4.7 & 5.2 & 5 . \\
\hline Other & - & - & - & - & - & - & - \\
\hline Policy banks & - & - & - & - & - & - & - \\
\hline Other Expenditure ${ }^{\mathrm{a}}$ & 23.2 & 28.2 & 32.6 & 33.6 & 41.5 & 46.3 & 49.4 \\
\hline State-owned commercial banks & 22.1 & 29.8 & 32.6 & 31.7 & 40.6 & 43.6 & 46.9 \\
\hline Other commercial banks & 29.1 & 31.3 & 37.5 & 39.7 & 41.9 & 47.4 & 47.9 \\
\hline Joint-stock commercial banks & 35.4 & 40.4 & 39.4 & 43.4 & 42.0 & 47.1 & 48.8 \\
\hline Other & 20.2 & 21.2 & 36.0 & 34.7 & 41.4 & 48.8 & 44. \\
\hline Policy banks & 7.8 & 8.8 & 10.6 & 18.7 & 29.7 & 21.8 & 26.1 \\
\hline
\end{tabular}

${ }^{a}$ Include personnel expenditures if it is not reported before.

Source: Bankscope. 
Table A7 NPL ratio in each SOCB

\begin{tabular}{llllrr}
\hline & \multicolumn{5}{c}{ (Based on the Five-Category } \\
\cline { 2 - 6 } & 2000 & 2001 & 2002 & 2003 & 2004 \\
\hline Agricultural Bank of China & - & 42.1 & 36.6 & 30.8 & 26.8 \\
Bank of China & 26.5 & 26.7 & 23.6 & 16.3 & 5.5 \\
China Construction Bank & 19.9 & 19.0 & 15.1 & 8.3 & 3.1 \\
Industrial and Commercial & 34.4 & 29.8 & 25.7 & 21.5 & 19.5 \\
$\quad$ Bank of China & & & & & \\
\hline
\end{tabular}

${ }^{\mathrm{a}}$ Source: Bankscope.

Table A8 Interest rate liberalization process

1. Liberalization of inter-bank lending rates

$1990 \quad$ Pilot liberalization of inter-bank lending market and rates

1996 Creation of unified inter-bank market

1996 Abolish the upper limit of inter-bank lending rates

2. Liberalization of bond market interest rates

1996 Market-based issuance of government bonds on pilot markets (stock markets)

1997 Utilization of the inter-bank market to deal in inter-bank bond repo transactions

Liberalization of the bond repo interest rates

1998 Market-based issuance of financial bonds by the policy banks

1999 Market-based issuance of government bonds

3. Market-based reform of lending and deposit rates

3.1. Foreign currency rates

3.1.1. Loans

1996 Introduction of foreign currency business in the commercial banks

2000 Liberalization of lending rates

3.1.2. Deposits

2000 Liberalization of over USD 3 million deposit rates

2002 Liberalization of small deposit rates of residents in foreign financial institutions

2003 Liberalization of deposit rates in Pound, Franc, Swiss franc and Canadian dollar

2003 Lower limit of deposit rates removed

2004 Liberalization of small deposits rates with maturity above 1 year.

(Continued.) 
Table A8 Continued

3. 2. RMB rates

3. 2. 1. Loans

1987 Surcharge until $20 \%$ on reference rates on loans (working capital)

1996 The band changes to $\pm 10 \%$ around reference rates

1998 Increase of upper limit to $20 \%$ (RCCs $50 \%$ )

1999 Increase of upper limit to $30 \%$ (RCCs and large enterprises $10 \%)$

2003 Increase of upper limit to pilot RCCs to $100 \%$

2004 Increase of upper limit to $70 \%$ and RCCs to $100 \%$. Lower limit remain at $90 \%$

2004 Liberalization of upper limit of RMB lending rates (excluding UCCs and RCCs, that increase until $130 \%$ above reference rates)

3. 2. 2. Deposits

1999 Negotiation on rates on over RMB 30 million deposits with maturity above 5 years for insurance companies

2002 Same scheme for Social Security Fund

2003 Same scheme for China Postal Saving and Remittance Bureau

$2004 \quad$ All kind deposit rates can adjust downward

Source: PBC (2005). 
Table A9 Foreign bank acquisitions

\begin{tabular}{|c|c|c|c|c|c|c|}
\hline Chinese bank & $\begin{array}{l}\text { Assets in } \\
2003 \text { (USD } \\
\text { in million) }\end{array}$ & $\begin{array}{l}\text { Share on assets } \\
\text { in } 2003 \\
\text { ( } \% \text { of bank } \\
\text { system assets) }\end{array}$ & Foreign bank & $\begin{array}{l}\text { Date of the } \\
\text { agreement } \\
\text { (or publication) }\end{array}$ & $\begin{array}{l}\text { Stake } \\
\text { acquired } \\
(\%)\end{array}$ & Observations \\
\hline China Everbright Bank & 47.63 & 1.4 & $\begin{array}{l}\text { Asian Development } \\
\text { Bank (ADB) }\end{array}$ & Oct 96 & 3.0 & \\
\hline Nanjing Commercial Bank & 3.6 & 0.1 & $\begin{array}{c}\text { International Finance } \\
\text { Corporation (IFC) }\end{array}$ & Nov 01 & 15.0 & $\begin{array}{l}\text { Acquisition of } 15 \% \\
\text { for USD } 27 \text { billion }\end{array}$ \\
\hline Bank of Shangai & 23.4 & 0.7 & $\begin{array}{l}\text { Hong Kong and } \\
\text { Shanghai Banking } \\
\text { Corp (HSBC) }\end{array}$ & Dec 01 & 8.0 & $\begin{array}{l}\text { Acquisition of } 8 \%, \\
\text { HSBC, IFC and } \\
\text { other foreign } \\
\text { investors maintain } \\
\text { a share of } 18 \%\end{array}$ \\
\hline $\begin{array}{l}\text { Shangai Pudong } \\
\text { Development Bank }\end{array}$ & 44.8 & 1.3 & Citigroup & Aug 02 & 4.6 & $\begin{array}{l}\text { Acquisition of } 4.6 \% \\
\text { for USD } 67 \text { billion. } \\
\text { Increase its } \\
\text { share to } 5 \% \text { in } \\
\text { November } 2003\end{array}$ \\
\hline Xi'an Commercial Bank & 3.1 & 0.1 & $\begin{array}{l}\text { IFC and Royal Bank } \\
\text { of Canada (RBC) }\end{array}$ & Sep 02 & 24.9 & $\begin{array}{l}\text { IFC acquires } 12.5 \% \\
\text { and RBC buy a } \\
12.4 \% \text { stake. First } \\
\text { operation in the } \\
\text { north-east part of } \\
\text { China }\end{array}$ \\
\hline
\end{tabular}




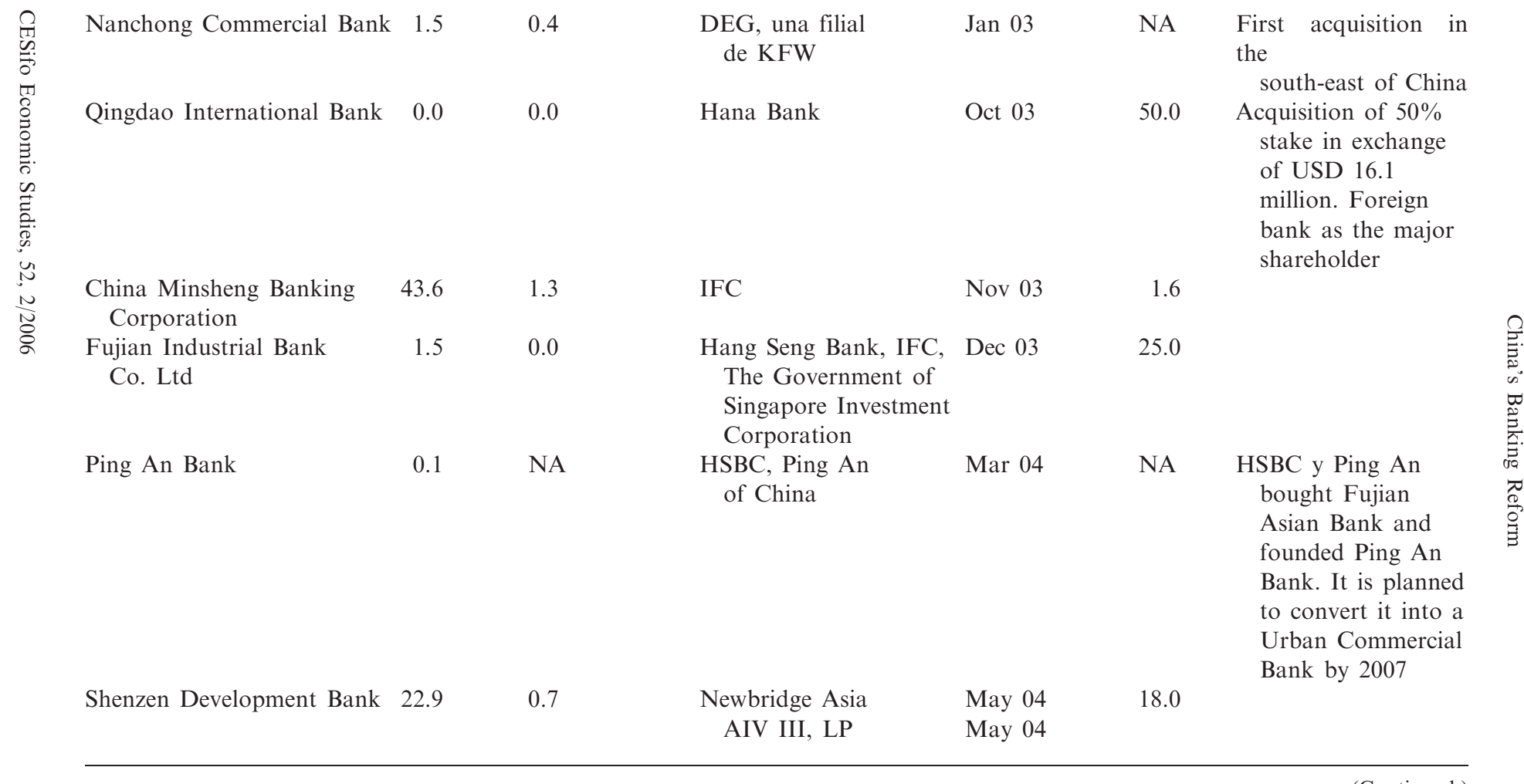


Table A9 Continued

$\underset{\perp}{\omega}$

\begin{tabular}{|c|c|c|c|c|c|c|}
\hline Chinese bank & $\begin{array}{l}\text { Assets in } \\
2003 \text { (USD } \\
\text { in million) }\end{array}$ & $\begin{array}{l}\text { Share on assets } \\
\text { in } 2003 \\
\text { ( } \% \text { of bank } \\
\text { system assets) }\end{array}$ & Foreign bank & $\begin{array}{l}\text { Date of the } \\
\text { agreement } \\
\text { (or publication) }\end{array}$ & $\begin{array}{l}\text { Stake } \\
\text { acquired } \\
(\%)\end{array}$ & Observations \\
\hline Bank of Communications & 114.8 & 3.4 & HSBC & Aug 04 & 20.0 & $\begin{array}{l}\text { Strategic investor. } \\
\text { HSBC will pay } \\
\text { USD } 1.7 \text { billion } \\
\text { for a stake of } 20 \%\end{array}$ \\
\hline Industrial Bank & 31.4 & 0.9 & $\begin{array}{l}\text { Hang Seng Bank } \\
\text { (HSBC), Government } \\
\text { of Singapore and IFC }\end{array}$ & Mar 04 & 25.0 & $\begin{array}{l}\text { Hang Seng Bank } \\
\text { acquires } 15.98 \% \text {, } \\
\text { Government of } \\
\text { Singapore } 5 \% \text { and } \\
\text { IFC through } \\
\text { Tetrad Investment } \\
\text { Pte Ltd. and } \\
\text { IFC } 4 \% \text {. }\end{array}$ \\
\hline Jinan City Commercial Bank & 2.4 & 0.1 & $\begin{array}{l}\text { Commonwealth Bank } \\
\text { of Australia }\end{array}$ & Nov 04 & 11.0 & \\
\hline Bohai Bank & NA & NA & Standard Chartered & Nov 04 & 20.0 & \\
\hline China Construction Bank & 429.3 & 13.4 & Bank of America & Jun 05 & 9.0 & $\begin{array}{l}\text { Acquisition of } 9 \% \\
\text { for USD } 2.5 \\
\text { billion. The new } \\
\text { owner will get a } \\
\text { seat on the CCB } \\
\text { Board }\end{array}$ \\
\hline
\end{tabular}

NA: not available.

Source: own calculations from Financial Times, Bankscope, He and Fan (2004) and CBRC. 
Table A10 Current situation on Financial Openness

\begin{tabular}{|c|c|c|}
\hline Area & Type & Description \\
\hline \multirow[t]{2}{*}{$\begin{array}{l}\text { Direct Investment and real } \\
\text { state transactions }\end{array}$} & Inflows & $\begin{array}{l}\text { No restrictions for non-residents (and also for profits repatriation and investment } \\
\text { liquidation) beyond the regional and sectoral limits }\end{array}$ \\
\hline & Outflows & $\begin{array}{l}\text { Requires the authorization of the SAFE, except some kind projects pre-authorized by } \\
\text { the State Council }\end{array}$ \\
\hline \multirow[t]{3}{*}{ Stocks and bonds } & Inflows & $\begin{array}{l}\text { Non-residents can purchase B shares (nominated in RMB) but the QFII can buy } \\
\text { A shares (for residents) with limitations }\end{array}$ \\
\hline & Outflows & $\begin{array}{l}\text { Only authorized resident financial institutions by the SAFE can purchase shares } \\
\text { abroad }\end{array}$ \\
\hline & & Issuance abroad or in foreign currency requires an administrative approbation \\
\hline \multirow[t]{3}{*}{ Money market instruments } & Inflows & Not allowed, neither purchases or issuances \\
\hline & Outflows & $\begin{array}{l}\text { Only resident financial institutions authorized by the SAFE can purchase money } \\
\text { market instruments abroad }\end{array}$ \\
\hline & & Issuance abroad or in foreign currency requires an administrative approbation \\
\hline \multirow[t]{2}{*}{ Credit operations } & Inflows & $\begin{array}{l}\text { In general, only for financial institutions, authorized enterprises and foreign-funded } \\
\text { enterprises can borrow. Nonetheless, financing under } 3 \text { months of maturity is not } \\
\text { subject to limitations }\end{array}$ \\
\hline & Outflows & $\begin{array}{l}\text { Only financial institutions with the SAFE approval. The advance repayment } \\
\text { of the loans in foreign currency is allowed, albeit wih limitations }\end{array}$ \\
\hline \multirow[t]{2}{*}{ Other financial instruments } & Inflows & Not allowed or allowed with strong requirements \\
\hline & Outflows & Either purchases or issuance are subject to prior approbation \\
\hline \multirow[t]{2}{*}{ Deposits operations } & Inflows & No restrictions \\
\hline & Outflows & Requires the approbation of the SAFE \\
\hline
\end{tabular}


Table A11 Steps in financial account liberalization

\begin{tabular}{|c|c|c|c|}
\hline Date & Objective & Area of reform & Description \\
\hline 2004 & Limit RMB convertibility & Capital inflows & $\begin{array}{l}\text { Limited convertibility of RMB for foreign banks FDI can only } \\
\text { be converted to RMB upon proof of domestic payment }\end{array}$ \\
\hline 2004 & Portfolio Investment & Capital outflows & $\begin{array}{l}\text { The national Security Fund and domestic insurance firms were } \\
\text { approved to invest part of this portfolios }\end{array}$ \\
\hline 2004 & QFII & Capital inflows & Soften the remaining restrictions \\
\hline 2002 & QFII & Capital inflows & $\begin{array}{l}\text { Qualified foreign institutional investors may invest in A shares } \\
\text { (for residents, in RMB) with some restrictions (maximum of } \\
\text { investment, maximum share in a single company, size of the } \\
\text { investor among others) }\end{array}$ \\
\hline 2001 & FDI & Capital outflows & $\begin{array}{l}\text { Pre-authorized investment overseas in strategic projects that } \\
\text { entail importing materials of China or foreign aid projects }\end{array}$ \\
\hline 2001 & Credit operations & Capital outflows & $\begin{array}{l}\text { Lifting restriction on advance repayments of loans in foreign } \\
\text { currency }\end{array}$ \\
\hline 2001 & Stock market & Capital outflows & $\begin{array}{l}\text { Domestic investors are allowed to invest in B shares } \\
\text { (for non-residents) with foreign deposits }\end{array}$ \\
\hline 1998 & Bond market & Capital outflows & Partial authorization to issue bond in foreign currency \\
\hline 1997 & $\begin{array}{l}\text { Announcement of financial } \\
\text { account liberalization by } 2000\end{array}$ & $\begin{array}{l}\text { Capital inflows } \\
\text { and outflows }\end{array}$ & \\
\hline
\end{tabular}


Table A12 Estimated government cost of recapitalization of ICB and ABC

\begin{tabular}{lll}
\hline SOCB & $\begin{array}{c}\text { Actual } \\
\text { figures }\end{array}$ & $\begin{array}{l}\text { Recapitalization } \\
\text { needs }^{\mathrm{a}}\end{array}$ \\
\hline Industrial and Commercial Bank of China & & \\
NPL & $86.05^{\mathrm{b}}$ & $63.45^{\mathrm{c}}$ \\
NPL/loans & $19.47 \%$ & \\
Provisions & 12 & $0.38^{\mathrm{d}}$ \\
Provisions/NPL & $13.95 \%$ & \\
Equity & $29.95^{\mathrm{e}}$ & 10.89 \\
Equity/assets & $4.40 \%$ & \\
Total & 74.72 & \\
Agricultural Bank of China & & \\
NPL & $79.81^{\mathrm{b}}$ & $63.02^{\mathrm{c}}$ \\
NPL/loans & $26.82^{\%}$ & \\
Provisions & 4 & $4.33^{\mathrm{d}}$ \\
Provisions/NPL & $4.80 \%$ & \\
Equity & 16.66 & 8.27 \\
Equity/Assets & $4.01 \%$ & \\
Total & & 75.62 \\
\hline
\end{tabular}

Author's own calculations

${ }^{\text {a }}$ Recapitalization needs are calculated as the difference between the actual levels of NPLs, provisions and equity and the necessary levels to achieve the objective values for the three ratios (NPL/loans, provisions/NPL and equity/assets) established by the CBRC for BoC and CCB at 2005 (4, 70 and $6 \%$, respectively).

${ }^{b}$ NPLs are obtained from the bank's ratio NPL/loans published by CBRC at 2004 and bank's total loans at end-2003 considering a loans' estimated growth rate of $10 \%$ in 2004 .

${ }^{\mathrm{c}} \mathrm{We}$ assume that the AMCs recover the same amount of NPLs as now $(7.2 \%$ in cash value). In this setting, the amount recovered by AMCs reduces the cost of recapitalization for the Chinese government.

${ }^{\mathrm{d}}$ We assume that the banks modify their NPLs before their provisions, so the necessary level of provisions is calculated over the objective NPLs.

' It includes the government's capital injection of USD 15 billion in 2005. 
A. García-Herrero et al.

Table A13 Estimated recapitalization needs for JSCBs

\begin{tabular}{lrcll}
\hline JSCB & NPL $^{\mathrm{a}}$ & Provisons $^{\mathrm{b}}$ & Equity $^{\mathrm{c}}$ & Total \\
\hline Bank of Communications & 5.71 & 0.47 & 1.97 & $8.15(2.15)$ \\
CITIC Industrial Bank & 1.27 & 0.53 & 1.01 & 2.81 \\
China Everbright Bank & 1.60 & -0.72 & 1.25 & 2.14 \\
China Merchants Bank & -0.32 & -0.10 & 1.55 & 1.14 \\
China Minsheng Bank & -0.66 & 0.26 & 1.44 & 1.05 \\
Hua Xia Bank & 0.04 & 0.00 & 1.70 & 1.74 \\
Shanghai Pudong Development & -0.46 & -0.18 & 1.23 & 0.59 \\
$\quad$ & & & & \\
$\quad$ Bank & 0.76 & -0.11 & 0.77 & 1.42 \\
Industrial Bank & -0.29 & 0.26 & 1.04 & 1.01 \\
Guangdong Development Bank & 3.54 & 0.28 & 1.48 & 5.30 \\
Total & & & & $25.33(19.33)$ \\
\end{tabular}

Author's own calculations

${ }^{\text {a }}$ Recapitalization needs are calculated as the difference between the actual level of NPLs and the necessary level to achieve the objective value of $4 \%$ for the ratio NPL/loans established by the CBRC for BoC and CCB at 2005.

${ }^{\mathrm{b}}$ Recapitalization needs are calculated as the difference between the actual level of provisions and the necessary level to achieve the objective value of $70 \%$ for the ratio provisions/NPL established by the CBRC for BoC and CCB at 2005. We assume that the banks modify their NPLs before their provisions so the necessary level of provisions is calculated over the objective NPLs.

${ }^{\mathrm{c}}$ Recapitalization needs are calculated as the difference between the actual level of equity and the necessary level to achieve the objective value of $6 \%$ for the ratio equity/assets established by the CBRC for BoC and CCB at 2005.

${ }^{\mathrm{d}}$ This bank has sold USD 6 billion to an AMC in 2004. The calculations have been done without taking into account this fact, so if we substract the USD 6 billion, recapitalization needs for Bank of Communications and total JSCBs are the values in brackets (2.15 and 19.33 USD billion, respectively). 


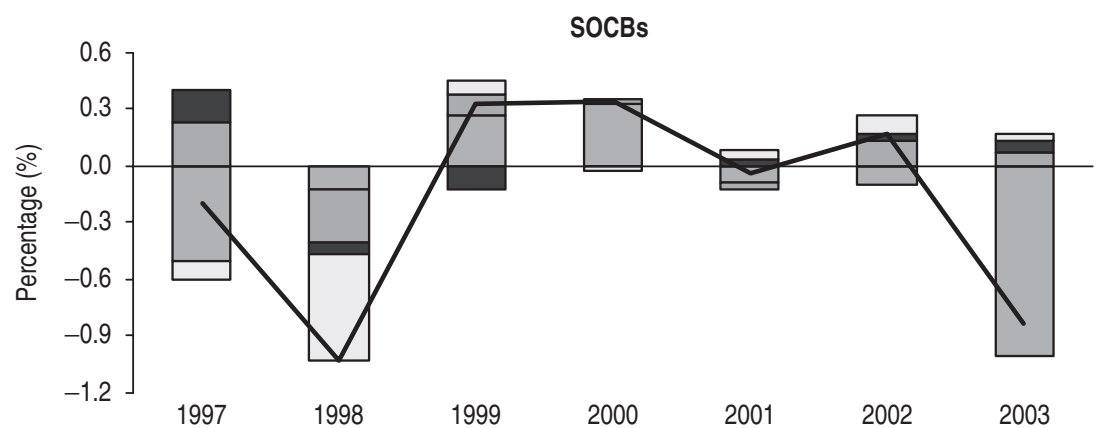

\begin{tabular}{|c|c|}
\hline $\begin{array}{l}\square \text { Net income/PPProfit } \\
\text { Operating income/assets } \\
\text { ROE growth rate }\end{array}$ & $\begin{array}{l}\square \text { PPProfit/operating income } \\
\text { בssets/equity }\end{array}$ \\
\hline
\end{tabular}
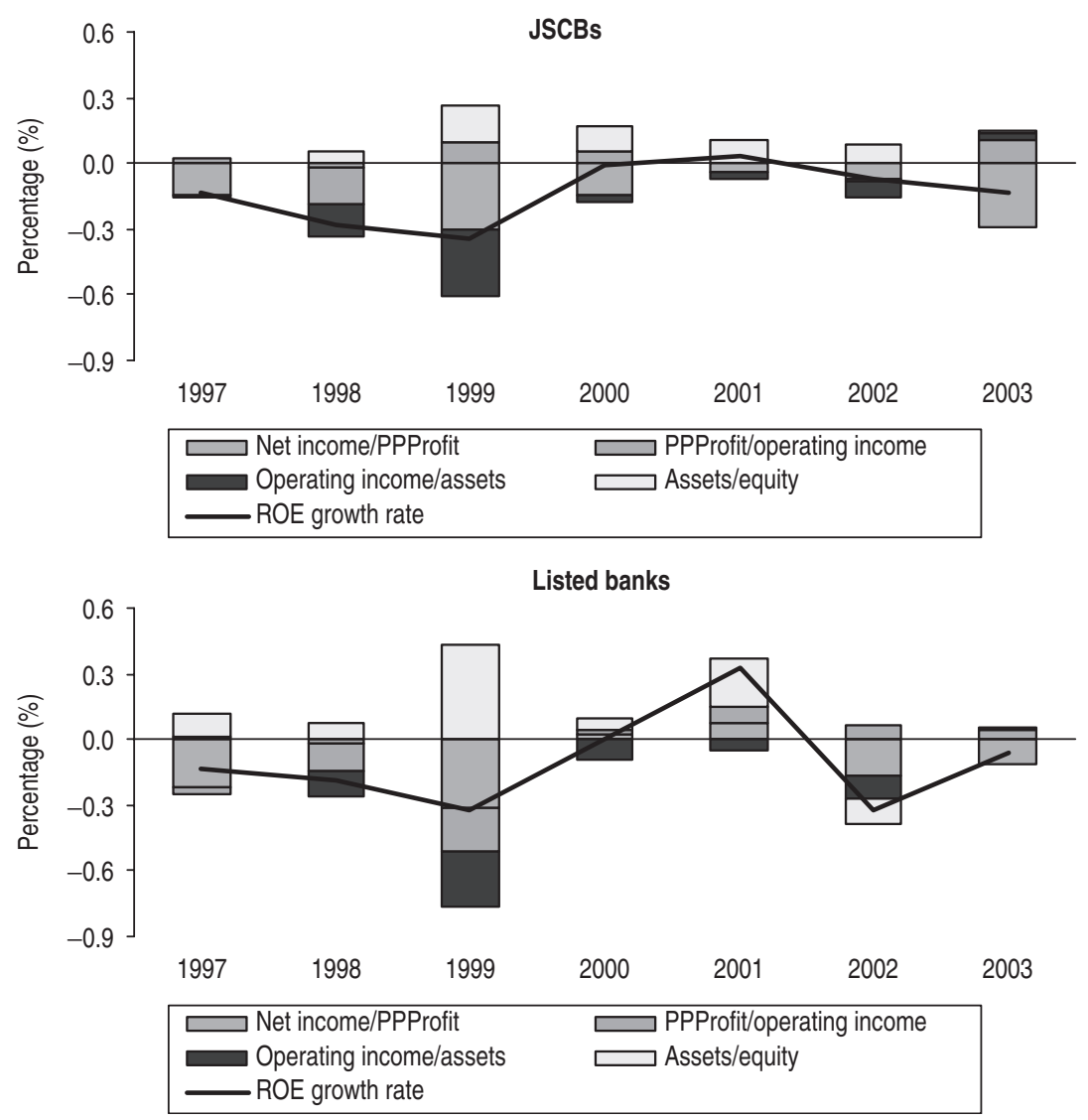

Figure A3 Contribution to the ROE growth rate 


\section{Appendix 2. Institutional setting of the Chinese banking system ${ }^{25}$}

Until 1979, China had a monobank financial system, as other centrally planned economies. The PBC was the only bank and, therefore, in charge of a large number of issues, such as the conduct of monetary policy, exchange policy, foreign reserve management, deposit-taking, commercial lending activities and the financing of development projects. The introduction of a two-tier banking system in 1979 was the first milestone in the modernization of the Chinese financial system.

Today, China's banking sector counts with two regulatory institutions, the central bank (PBC) and the $\mathrm{CBRC}$, both ultimately overseen by the State Council (the cabinet) and the rest of the financial system (Figure A2-1).

The $\mathbf{P B C}$ is currently in charge of the monetary policy and the liquidity of the financial system. It aims at promoting economic growth and price stability. The PBC manages the interest rate bands for loans and deposits, since the interest rates are not fully liberalized yet, the reserve requirements and other instruments affecting banks' liquidity. The PBC also monitors and regulates the credit expansion of a large share of the banking system.

The CBRC was established in April 2003 to take over the regulatory and supervisory functions of the banking sector so that the PBC could concentrate on monetary policy matters. Its objectives include protecting consumers and depositors, maintaining the stability in the banking system, enhancing banks' competitiveness, encouraging competition, educating the public on the role of finance and eradicating financial crime. To this end, it focuses on the strength of financial institutions, capital adequacy issues, and the restructuring of the banking sector.

There is also a number of non-bank financial institutions in the Chinese banking system. The main ones are the TICs, created in the 1980s to support the development of the private sector and to provide financing outside the credit quotas imposed to commercial banks. Some TICs act as the investment instrument of local or provincial governments. Some others are intermediaries of international funds (through bond issues or syndicated medium and long-term loans) to finance local companies and infrastructure and construction projects. Other important non-bank financial institutions are AMCs, established in 1999 to receive the NPLs from the SOCBs and recover them through different asset resolution techniques. Securities companies have played an important role in the

25 Drawn from García Herrero and Santabárbara (2004). 
China's Banking Reform

\section{Regulatory institutions}

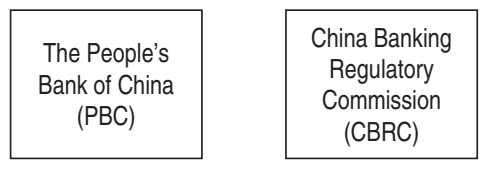

Non-bank financial institutions

\begin{tabular}{|c|c|c|c|}
\hline $\begin{array}{c}\text { Trust and } \\
\text { Investment } \\
\text { Corporations } \\
\text { (TICs) }\end{array}$ & $\begin{array}{c}\text { Asset } \\
\text { Management } \\
\text { Companies } \\
\text { (AMCs) }\end{array}$ & $\begin{array}{l}\text { Securities } \\
\text { companies }\end{array}$ & $\begin{array}{l}\text { Insurance } \\
\text { companies }\end{array}$ \\
\hline
\end{tabular}

\section{Banking institutions}

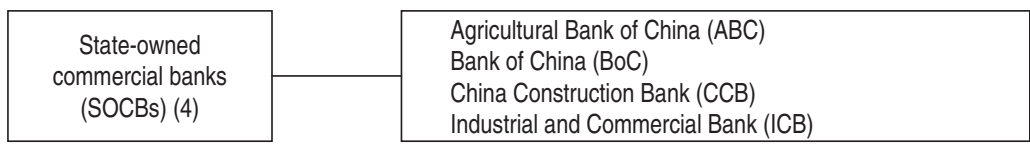

\begin{tabular}{|c||l|}
\hline \multirow{2}{*}{\begin{tabular}{c|} 
Policy lending \\
banks (3)
\end{tabular}} & $\begin{array}{l}\text { Agriculture Development Bank of China } \\
\text { Export-Import Bank of China } \\
\text { China Development Bank }\end{array}$ \\
\cline { 2 - 3 } & \\
\hline
\end{tabular}

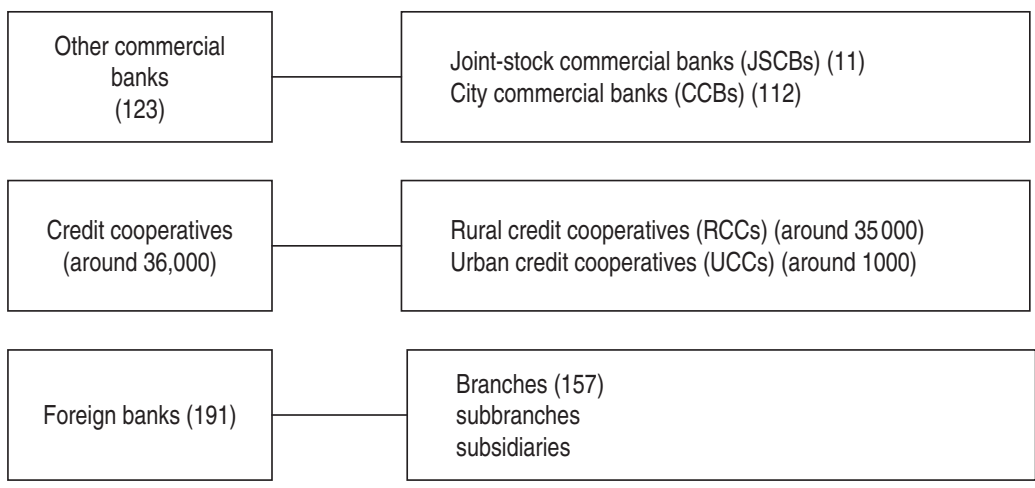

Figure A2-1 Structure of the Chinese financial system

development of the stock exchanges since the 1990s. Their ownership has become more diversified with an increasing participation of the private sector. Insurance companies, in turn, are basically in State hands although most of the newly created companies are joint-stock ones and have shifted their focus from market share to economic return. Since China's WTO entry, foreign companies have expressed great interest in the Chinese insurance sector. 
The core of the Chinese financial system, the banking system, includes four large SOCBs, three policy lending banks and a large number of other commercial banks, credit cooperatives and financial institutions. Among the commercial banks, there are eleven JSCBs, which were initially created to provide specialized product niches but now offer a full range of financial services. At the local level, there are more than $110 \mathrm{CCBs}$, 1000 UCCs, and 35000 RCCs providing basic banking services.

The four SOCBs, ${ }^{26}$ the $\mathrm{ABC}$, the $\mathrm{BoC}$, the $\mathrm{CCB}$ and the ICB, were established in the 1980s. They were assigned sector policy objectives, previously in the hands of the PBC with the monobank system. In 1994, with the creation of the policy-lending banks, their responsibilities were restricted to commercial purposes (Karacadag 2003). Although their assets have fallen in the last two decades (from 72 percent of the total assets in the banking system in 1994 to 55 percent at the end of 2004), they are still very large. In fact, they are among the biggest banks in the world, with total assets in above USD 2000 billion and an extensive branch network (with a total of 42000 offices) and over 700000 employees at the end of 2002.

Three policy-lending banks were created in 1994 to carry out the development policies previously assigned to the SOCBs and hold about 10 percent of the total bank assets. These are the Agricultural Development Bank, the China Development Bank and the ExportImport Bank of China. Their main objectives are agricultural development, national infrastructure and foreign trade, respectively, with special attention to the poorer, western and central regions. Policy-lending banks fund themselves through central bank loans, government deposits and the issuance of government-guaranteed deposits held by commercial banks. They also lend extensively to the government. Even more than in the case of SOCBs, profitability is only a residual objective for their managers.

There are a number of other commercial banks in the Chinese banking system, with a diverse ownership structure and geographical scope. Part of them has been used as an experiment for the liberalization process of the financial system and others are specialized in some market niches. There are two main groups: JSCBs and CCBs:

JSBCs are partially owned by local governments and SOEs, and sometimes by the private sector. There are currently eleven banks - five of

26 In the process of establishing a two-tier banking system, the government in 1979 first removed the monopolistic position of the $\mathrm{PBC}$ by establishing the $\mathrm{ABC}$, the $\mathrm{BoC}$ and the $\mathrm{CCB}$. The $\mathrm{ABC}$ objective was to foster rural banking business and to take the supervisory authority of a network of rural credit cooperatives that had been providing small-scale rural banking. The $\mathrm{BoC}$ was assigned foreign currency transactions, while the $\mathrm{CCB}$ focused on the construction sector. The government completed a two-tier banking system by removing commercial banking activities from the $\mathrm{PBC}$ and transferring them to the ICB, the fourth specialized bank, established in 1984. 
which are listed on local stock markets - and account for 15 percent of the total bank assets. The biggest ones are Bank of Communications, China Minsheng Bank, ${ }^{27}$ China Everbright Bank, China Merchants Bank, Shanghai Pudong Development Bank and Shenzen Development Bank. The JSCBs finance small SOEs and firms with partial private ownership, including SMEs. They maintain much smaller branch networks than SOCBs, typically confined to the region of origin or to the fast-growing coastal area, although they are generally allowed to operate at the national level. These banks are the most market-oriented, with better governance and management and have experienced the fastest expansion in the last few years.

Since the mid-1990s, CCBs have been created by restructuring and consolidating UCCs. There are currently 112, accounting for about 5 percent of the total assets in 2004. Their capital is in the hands of urban enterprises and local governments. They are not allowed to operate at the national or regional scale unlike the JSCBs, which is their major competitive disadvantage. Finally, CCBs lend to SMEs, collective and local residents in their municipalities.

RCCs and UCCs were established in the 1980s as a mechanism to diversify the financial system and to finance projects in areas where resources were scarce. They typically attract deposits from rural areas or small towns and provide credit to SMEs or peasants, a good part of which is subsidized. In fact, their lending policies are subject to the control of the local public authorities As of June 2003, there were about 35000 RCCs, providing 80 percent of the rural finance, and 1000 UCCs. Their share of assets was 10.4 percent as of the end of 2004, marking a steady reduction since 1995 (with 14.3 percent of the total bank assets). This is mainly due to their inability to expand lending even if their deposits continue to expand. Nowadays, RCCs are more important and numerous than urban ones, after the consolidation of the latter into CCBs. Finally, RCCs are the worst performing financial institutions in China, with very poor governance and the highest NPL ratios.

Foreign banks play a very limited role in the Chinese banking system. As of September 2003, there were 191 licensed foreign banking institutions, among which 157 are branches, 11 subbranches and 15 subsidiaries incorporated locally with eight branches. $^{28}$ They hold 0.3 percent of the local currency lending market and around 13 percent in the foreign currency lending market; all in all about 1.5 percent of the total bank assets.

\footnotetext{
27 China Minsheng Bank is the only one fully privately owned. It focuses on lending to the private sector, including joint ventures with foreign partners.

28

Ping (2003).
} 